\title{
Middle Stone Age Technology and Cultural Evolution at Magubike Rockshelter, Southern Tanzania
}

\author{
J. Jeffrey Werner • Pamela R. Willoughby
}

Published online: 7 June 2017

(C) The Author(s) 2017. This article is an open access publication

\begin{abstract}
This paper contributes new information to the body of evidence for Middle Stone Age tool-use in Tanzania. Magubike rockshelter is located in an archaeologically unexplored region of the south-central part of the country, and thus fills a significant geographical gap between sites further to the north and those to the south in Zambia and Mozambique. Early analysis of a portion of the lithic materials demonstrates parallel changes in lithic reduction intensity, raw material preference and typology. This article explores possible explanations for this pattern, including the possibility that they reflect changes to local environment, and suggests avenues for future research.
\end{abstract}

Résumé Cet article apporte de nouvelles informations à l'ensemble des preuves sur l'utilisationd'outille de l'âge de pierre moyen en Tanzanie. L'abris sous roches de Magubike est situé dansune région archéologique inexplorée de la partie sud-centrale du pays, et remplit ainsi unespace géographique entre les sites plus au nord et celles du sud en Zambie et au Mozambique. L'analyse préliminaire d'une partie des matériaux lithiques démontre des changementsparallèles dans l'intensité de réduction lithique, la préférence des matières premières

Archaeological Time period: Middle Stone Age; Later Stone Age Country: Tanzania

Region: Iringa Region, Southern Highlands

J. Werner · P. R. Willoughby $(\bowtie)$

Department of Anthropology, University of Alberta, Edmonton, AB T6G 2H4, Canada

e-mail: Pam.Willoughby@ualberta.ca et de latypologie. Cet article explore les explications possibles de ce modèle, y compris la possibilitéqu'elles reflètent des changements de l'environnement local, et propose des pistes pour larecherche future.

Keywords Lithic analysis · Palaeolithic · Technology, reduction intensity $\cdot$ Middle Stone Age

\section{Introduction}

Fossil and genetic evidence indicate an African origin for modern Homo sapiens during the Middle Stone Age (MSA), by 195,000 years ago (Cann et al. 1987; Fu et al. 2013; Grine 2016; McDougall et al. 2005; White et al. 2003). This speciation event occurred amidst a mosaic backdrop of significant behavioural change, which may have begun as early as $\sim 500,000$ years ago and became consolidated in the Later Stone Age (LSA) (Burdukiewicz 2014; Henshilwood 2007; McBrearty 2013; McBrearty and Brooks 2000; Shea 2011; Wilkins et al. 2015). During this time humans began to create sophisticated tools from both lithic and perishable materials such as wood and bone (Barham 2002; Leplongeon 2014; Wilkins et al. 2012; Wilkins and Chazan 2012; Yellen et al. 1995), to engage in long-distance exchange (Barut 1994; Mehlman 1989), to exploit a variety of ecosystems including marine coastlines (Arzarello et al. 2013; Barham 2002; Broadhurst et al. 2002; Drake et al. 2011; Jerardino and Marean 2010; Marean 2011; Marean et al. 2007; Walter et al. 2000), and to produce art and personal adornment (Bar-Yosef Mayer et al. 2009; D’Errico et al. 2005; Henshilwood 
et al. 2002, 2004, 2009; Hovers et al. 1997; Mackay and Welz 2008; Miller and Willoughby 2014; Willoughby 2007).

Many believe that these innovations were stimulated, at least in part, by changes in climate and environment during the Late and Middle Pleistocene (MIS 6 to MIS 2) (Ambrose 1998; Basell 2008; Blome et al. 2012; Chase 2010; Drake et al. 2013; Larrasoaña et al. 2013; B. A. Stewart and Jones 2016). Amongst climate advocates, this view is often expressed in one of two ways. Some contend that repeated episodes of severe and unpredictable glacial climate encouraged the development of cultural buffering mechanisms as home ranges declined in productivity (Ambrose 1998; Clarkson 2013; Henshilwood and Marean 2003; J. R. Stewart and Stringer 2012). New adaptive and social strategies thus became required to cope with changing patterns of resource availability and distribution, as well as greater exposure to non-kin. The increasingly patchy and unpredictable distribution of food and water resources in some areas may have caused a shift towards greater residential or logistical mobility and a preference for technologies such as microliths that made more efficient use of cores and blanks, and were potentially more portable (McCall 2007). A general trend towards exoticism in lithic raw material preference during the late MSA in many areas is also thought to support the notion that individual groups became more mobile, or were increasingly embedded in far-reaching networks of exchange (Barut 1994; Clarkson 2013). Alternately, others have proposed that stable conditions within refugia were necessary for cultural experimentation (Jacobs et al. 2008; Ziegler et al. 2013). This version of the argument tends to draw on demographic models such as those of Powell et al. (2009) and Henrich (2004) that show that larger populations are more likely to innovate due to a greater pool of potential innovators. Large populations may also be more resistant to information loss as a result of stochastic effects because cultural knowledge is distributed across more members. However, linking dynamic large-scale climate processes, such as those preserved in marine isotope stages, to site-specific material behaviours is difficult if not misguided. As a result, many have called for paleoenvironmental work to be carried out on finer scales (Grine 2016; Roberts et al. 2016).

With respect to the paleoenvironmental context of eastern Africa several high resolution climate records are available that indicate the existence of a variety of environments, which likely responded to climate change very differently (Faith et al. 2016; Lahr and Foley 2016). The unique conditions of these localized environments paired with relatively isolated populations may even be responsible for the significant behavioural diversity observed between eastern African sites during the MSA (Clark 1988; Douze and Delagnes 2016; McBrearty and Brooks 2000; Tryon and Faith 2013). Indeed, archaeologists have struggled to identify archaeological features that are common to all, or even many, eastern African MSA localities. Furthermore, a large proportion of eastern Africa sequences exhibit complex or indistinct patterns of temporal change that are for the most part typified by continuity in typological products through time (Douze and Delagnes 2016). For these reasons, several scholars have called for the creation of location- specific models of cultural change that can be aggregated to form a more coherent regional picture (Douze and Delagnes 2016; Mitchell 2008; B. A. Stewart et al. 2012; Tryon and Faith 2013). One part of eastern Africa for which more data would be useful for completing this regional picture is southern Tanzania. Since the majority of archaeological survey and excavation has occurred at places such as Mumba and Nasera filling these gaps in the south of the country is vital for linking the MSA records of Zambia and Mozambique with those further north.

Several newly discovered sites located in the highlands of southern Tanzania, containing comprehensive MSA sequences, may contribute valuable data to questions of local adaptation in this area (Miller and Willoughby 2014; Willoughby 2012). Early work on the lithic assemblage from the Magubike archaeological site in the Iringa province of southern Tanzania shows gradual, unidirectional change in lithic reduction intensity, artefact typology and raw material economy. This paper describes the available lithic evidence and explores possible reasons for the patterns, including broad-scale demographic and environmental factors active at that time.

\section{The Magubike Archaeological Site}

The Magubike archaeological site (Figs. 1, 2, 3) is a granite rockshelter situated in the Iringa province of southern Tanzania, near the town of the same name. It is located at latitude $7^{\circ} 45.790^{\prime} \mathrm{S}$ and longitude $35^{\circ} 28.399^{\prime} \mathrm{E}$, at an elevation of $1541 \mathrm{~m}$. It was assigned SASES number HxJf-1. The modern landscape consists of large granite kopjes and outcrops cut through by 


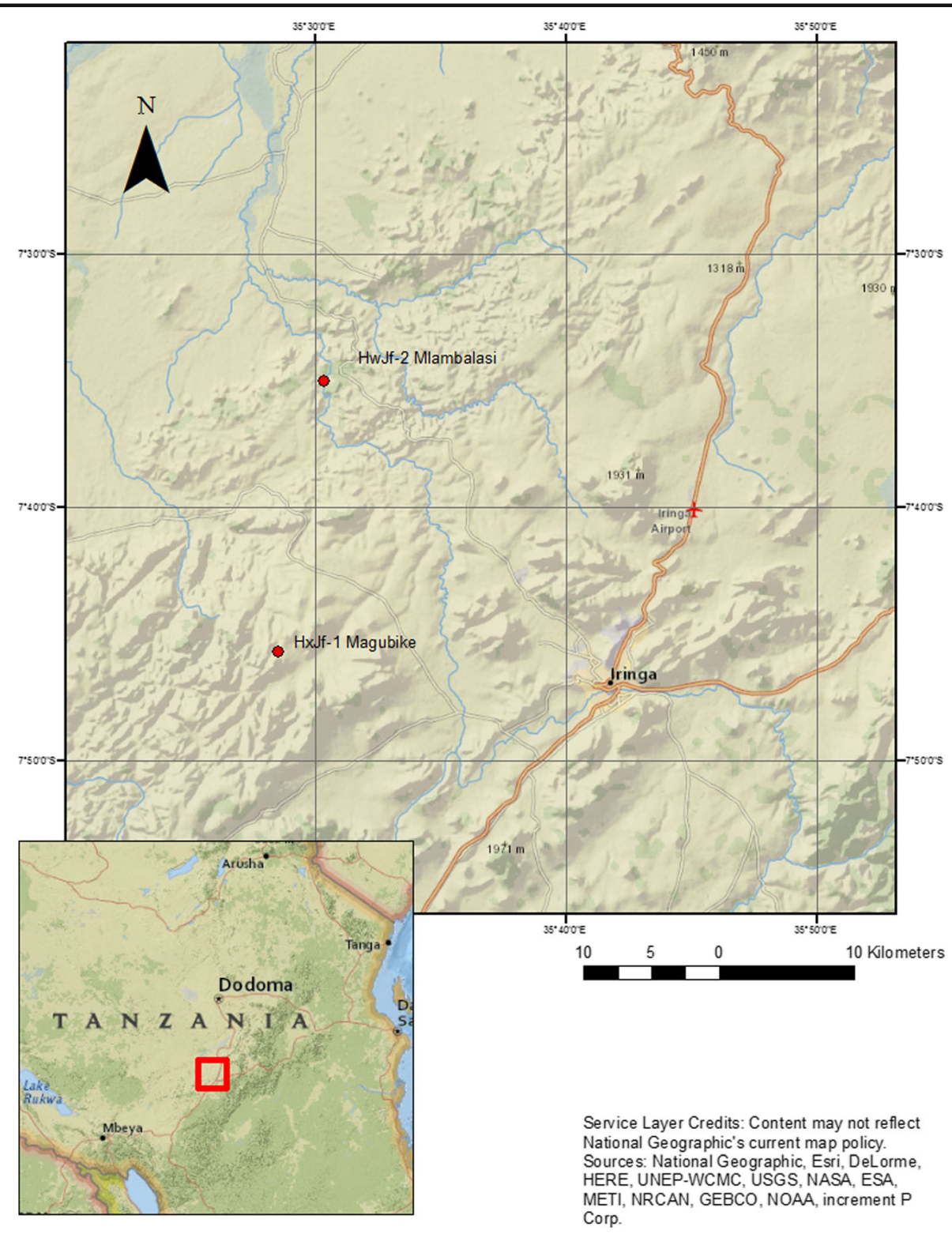

Fig. 1 Map of Tanzania showing the Iringa Region and Magubike rockshelter

rivers and smaller ephemeral streams. As these kopjes eroded they left numerous shelters, which were the focus of late Pleistocene and Holocene human occupation in the area. Woodland and moist savannah plants form the dominant vegetation and dry montane forests are clustered on the hills and other high places. Climatologically the region is classified as dry to sub-humid or semiarid with a long, dry season and about $75-100 \mathrm{~mm}$ of annual rainfall. The geology of Iringa is very old, and is mainly comprised of Precambrian migmatites and granite that formed during the late Archean. Much of the subsequent geology of the area represents the reworking of these deposits. The sedimentology of the shelter consists mainly of unconsolidated aeolian silts interdigitated with disintegrated elements of the granite bedrock and shelter roof.

Initial exploration of the area around the town of Magubike was undertaken by Willoughby in 2005 , and excavations of the site in 2006, ' 08 and ' 12 revealed substantial historic, Iron Age, Later Stone Age (LSA) and MSA deposits in three different locations (Willoughby 2012). Materials recovered from the Magubike site include lithics, faunal remains, a number of MSA hominin teeth (Willoughby et al., n.d.), ostrich 
Fig. 2 The Magubike rockshelter (photo: P. Willoughby)

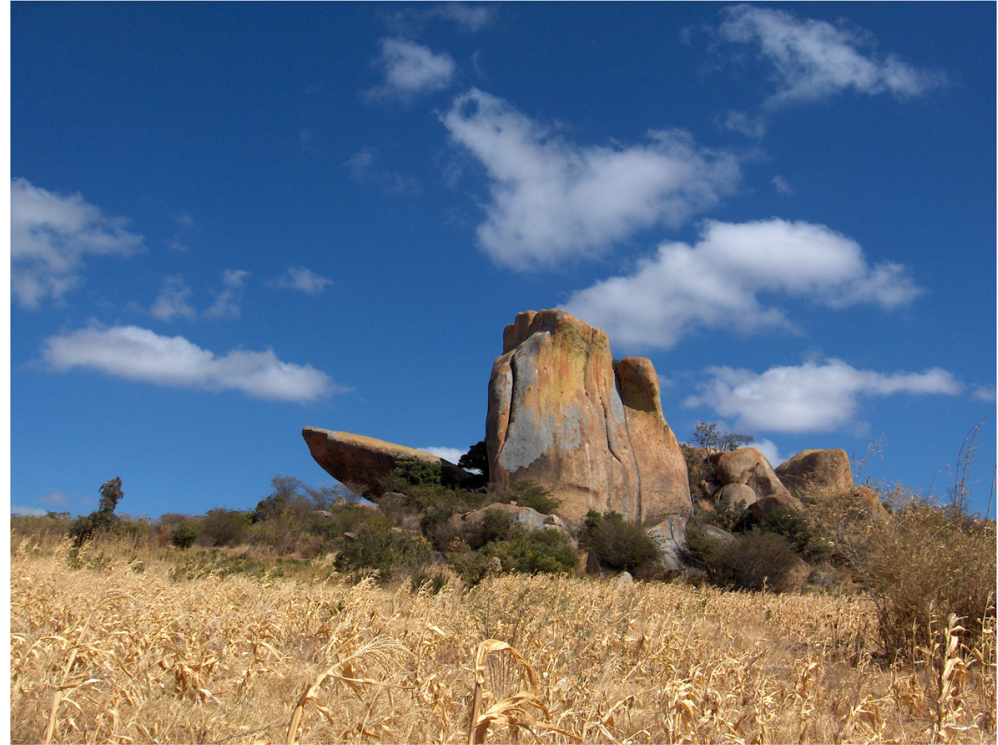

eggshell beads dating to the MSA, LSA and Iron Age (Miller and Willoughby 2014), as well as evidence of pottery use, iron smelting and blacksmithing (Willoughby 2012). A survey of the surrounding terrain was also undertaken in 2008 with the aid of topographic and geological maps to locate additional sites as well as potential lithic raw material sources.

The initial excavations of the site involved $1 \mathrm{~m}$ squares excavated in arbitrary $10 \mathrm{~cm}$ levels due to the massive nature of the deposits. The stratigraphic profiles produced by the excavation were indistinct, and the artefacts were distributed throughout the sediment rather that clustered into what could be interpreted as discrete horizons or living floors. A patina of chemical precipitate on many of the artefacts suggests the movement of mineral rich water through the sediments, which may imply a degree of disturbance. Nevertheless, there is no evidence of size-based sorting or preferential artefact

Magubike Archaeological Site - Plan Map

------- Present Day Roof-Line

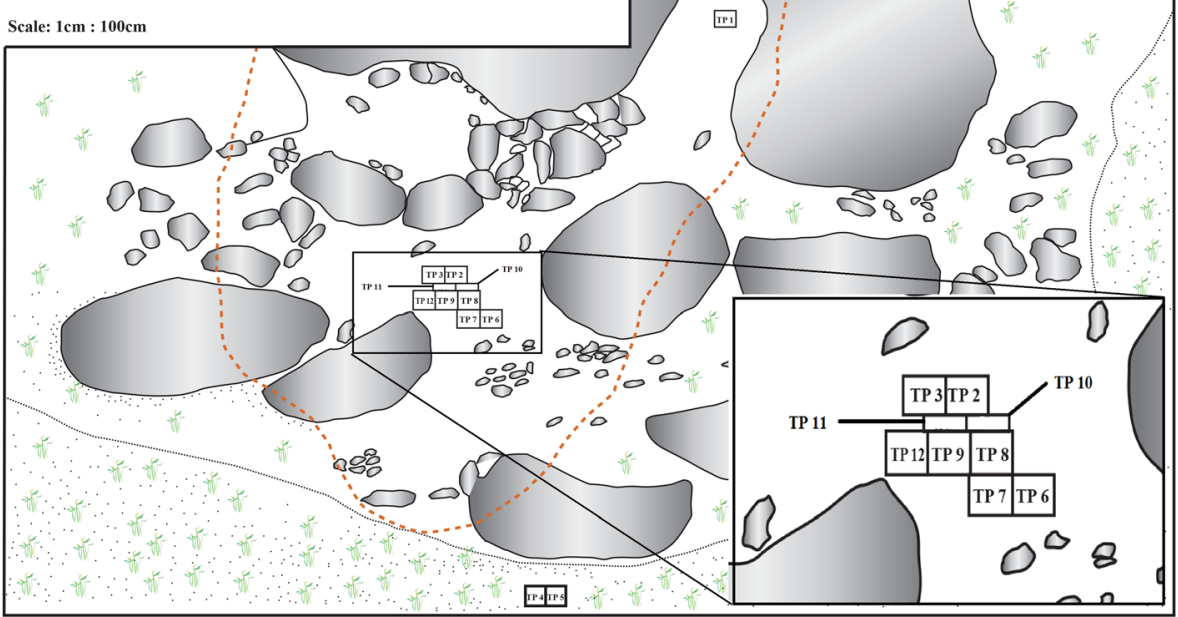

Fig. 3 Plan view of the site showing location of test pits (from base map produced by Frank Masele) 
orientation. Although we have chosen to approach the chronology of Magubike very conservatively until we have conducted the necessary geoarchaeological analyses the deposits appear to be largely intact. A case for stratigraphic coherence is further supported by several sequential AMS radiocarbon and preliminary optically stimulated luminescence (OSL) dates (see below).

Artefacts were assigned to techno-cultural traditions based on a number of variables. Of these, the presence of discoidal and Levallois-like core technology in the deepest deposits of the main shelter suggest an MSA origin, as does the existence of Levallois flakes with dorsal shaping and facetted platforms. These flake and blade blanks were most often transformed into points and scrapers, or used without further modification (Ambrose 2001; Brantingham and Kuhn 2001; Tryon et al. 2005; Van Peer 1992). A higher diversity of lithic raw materials and a greater emphasis on metamorphic stones in what we have defined as MSA layers also indicates an important difference in raw material economy. The levels assigned to the LSA conversely, exhibit characteristics similar to other well-studied LSA sequences in Tanzania, such as those from Mumba and Nasera (Mehlman 1989; Prendergast et al. 2007). Namely, they show an almost exclusive reliance on vein and massive quartz for the production of small backed pieces, which some have referred to as microliths, although there is now debate as to the appropriateness of such a term (Pargeter and Brandt 2015). These levels are also free of Levallois cores or flakes, and generally show a decreased emphasis on radial flaking, with the majority of blanks achieved using bipolar methods. Finally, the Iron Age and historic/modern levels nearest to the surface contained lithic artefacts similar in material and typology to the LSA but are associated with pottery, iron, slag and ceramic furnace fragments.

In two parts of Magubike, there are MSA occupations directly under LSA and Iron Age ones. However, in test pit 1 , there was almost $40 \mathrm{~cm}$ of sediment between the end of the LSA at $70 \mathrm{~cm}$ below the surface and the start of a dense MSA deposit at $110 \mathrm{~cm}$ below the surface. In this $40 \mathrm{~cm}$ gap there were only a handful of stone artefacts with types characteristic of both periods. In test pit 5 , which was excavated below the main shelter in 2008, a $2.5 \mathrm{~m}$ deep sequence was uncovered, which contained a historic level, then Iron Age, then an LSA dominated by small quartz artefacts, then a larger LSA, then a mixed LSA/MSA layer, and finally $90 \mathrm{~cm}$ of MSA artefacts. The small and large LSA sequence is similar to that excavated nearby at Mlambalasi rockshelter (SASES \#HwJf-2) in 2006 (Willoughby 2012); the former LSA was dated to the Holocene, the latter to the late Pleistocene. It is only in the main shelter that organic materials are directly associated with Stone Age artefacts (Willoughby 2012). No chronometric dates are available yet except for those directly under the shelter, which includes Test Pits 2, 3, and 6 through 12.

\section{The Chronology of Magubike}

Although the oldest deposits at the site are thought to date to the MSA primarily on the basis of lithic typology, several chronometric methods have been used at the Magubike site in order to establish the antiquity and continuity of the cultural sequence (Table 1). Three ostrich (Struthio camelus) eggshell (OES) beads from the MSA levels at Test pit 12 were directly dated using AMS radiocarbon to $47,750 \pm 750(\mathrm{OxA}-27,626)$, $31,810 \pm 180$ (OxA-27,627) and 13,125 \pm 50 (OxA27,625) years uncalibrated BP (Miller and Willoughby 2014). Levels $70-80 \mathrm{~cm}, 80-90 \mathrm{~cm}$ and $40-50 \mathrm{~cm}$, from which the beads respectively derived, date to the established chronology of the LSA and late MSA (McBrearty and Brooks 2000). The dates are also consistent with the cultural materials found in these levels. However, the non-sequential dates of several of the beads suggest that they were likely vertically displaced in the sediment to some extent. Several more OES from adjoining test pits provide support for these dates (Table 1).

The second chronometric method that was attempted was electron spin resonance (ESR), which was performed on mammal teeth and giant land-snail shells (Achatina) associated with archaeological materials. It became apparent early on that the dates obtained from this technique could not be meaningfully correlated with depth. Further testing by Anne Skinner also showed that ESR and radiocarbon dates obtained from the same samples were consistently and significantly different (up to a maximum difference of 90,000 years). The unusually high radiation level of Magubike's bedrock geology is thought to be a confounding factor. Even though the dates derived from mammal teeth place the MSA occupation of the site somewhere between 260,000 and 40,000 years ago, until the substantial issues with ESR can be resolved, we have chosen to ignore them for the purpose of interpreting the site's chronology. 


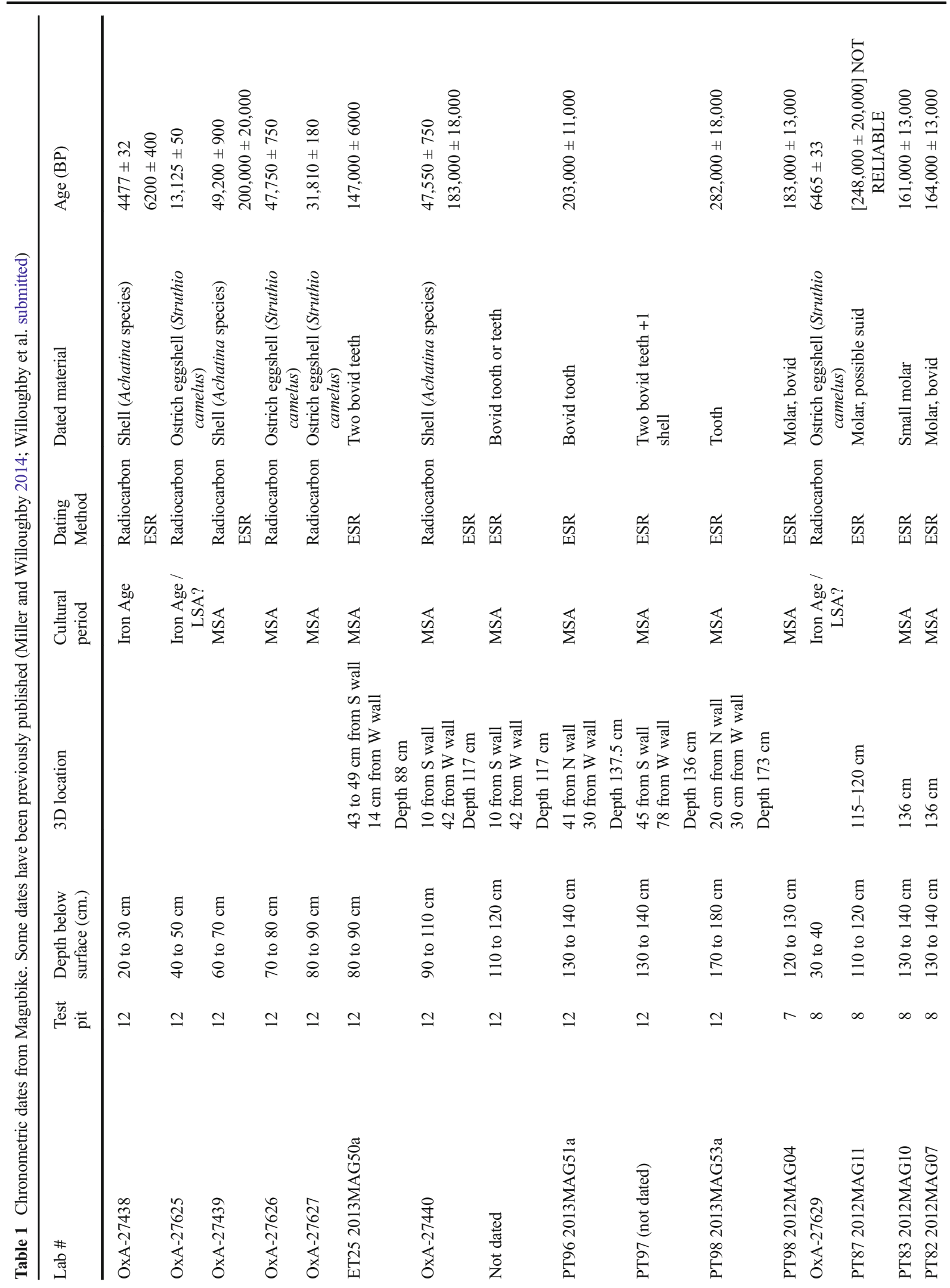




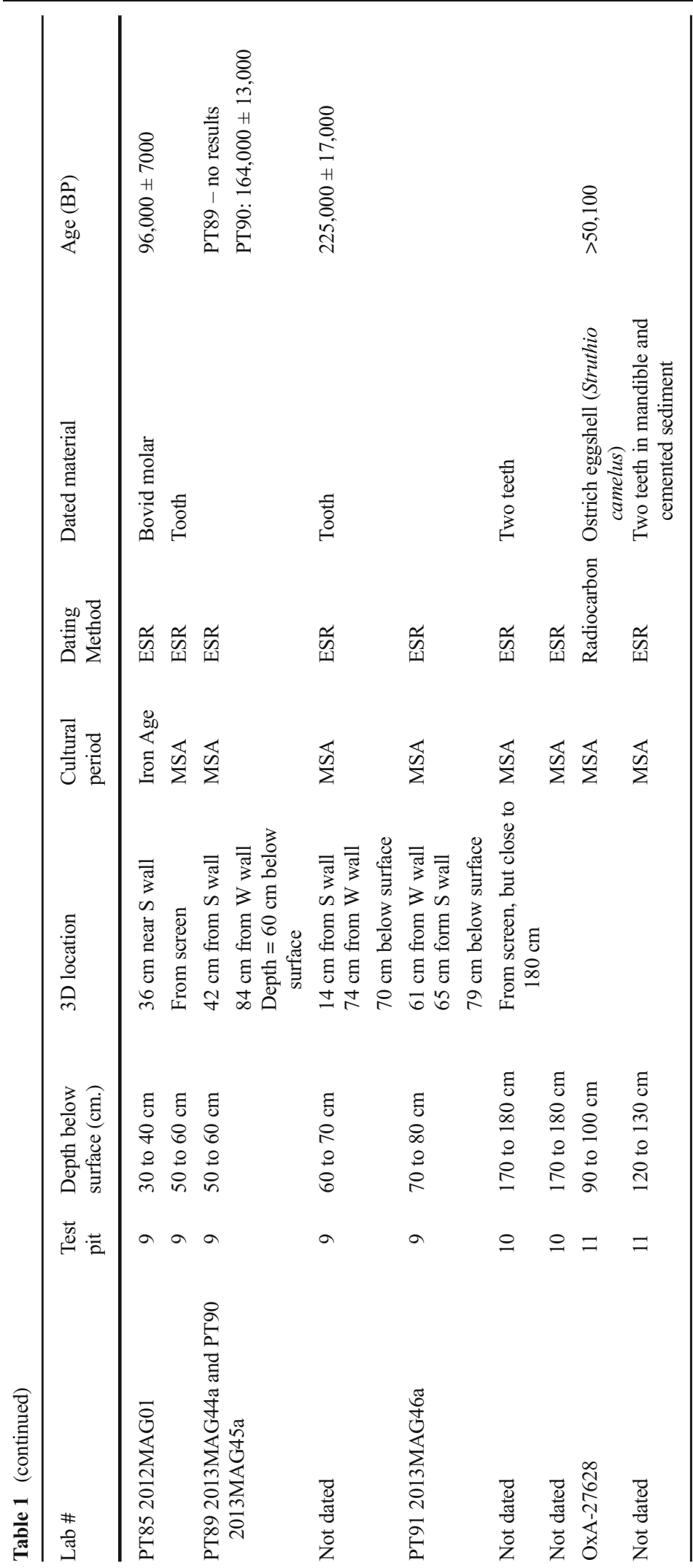


The last dating method used at Magubike was optically stimulated luminescence (OSL) on associated sediments. Six samples were collected from the following depths of Test Pit 12 in 2012: $25 \mathrm{~cm}$ (associated with Iron Age artefacts), and $55 \mathrm{~cm}, 97 \mathrm{~cm}, 132 \mathrm{~cm}, 163 \mathrm{~cm}$ and $194 \mathrm{~cm}$ (all associated with MSA materials). Preliminary OSL dates show close agreement with those obtained from the AMS radiocarbon on snail shells and the OES beads, and indicate the Middle Stone Age deposits in the main site probably date to between 100,000 and 50,000 years ago (James Feathers, personal communications).

In summary, three independent chronometric methods have been used to date the site. AMS radiocarbon revealed a high-resolution record between $\sim 4000$ and 50,000 years ago. To date the materials from the site that surpass the radiocarbon limit we used ESR to date snail shells and mammal teeth and OSL to date associated sediments. The ESR dates do not accord well with those achieved with the radiocarbon ones, likely as a result of the highly radioactive sedimentary context. Preliminary OSL ages indicate the site was first occupied during the MSA by at least $64.8 \pm 9.4$. On the basis of AMS and OSL it appears as though the MSA continued at Magubike until approximately 40,000 years ago, at which point there is a transition to LSA and/or Iron Age materials.

\section{Test pit 12}

The materials that are presented in this article originate from under the main overhang of the shelter (Test pit 12), which was excavated during the 2012 field season (Fig. 4). Test pit 12 measured $1.35 \times 1.0 \mathrm{~m}$ and reached a depth of $180 \mathrm{~cm}$, at which point the bedrock was contacted. It is immediately adjacent to Test pit 3, which yielded six hominin teeth in 2006 (Willoughby 2012). Included amongst the archaeological deposits were lithic artefacts, faunal remains, ostrich eggshell beads, iron slag, clay furnace fragments and potsherds. Everything below $50 \mathrm{~cm}$ from the modern surface of Test pit 12 belongs to the MSA, above which were $50 \mathrm{~cm}$ of historic and/or Iron Age materials (Fig. 4). At the west end of Test pit 12 was a depression with iron fragments and slag - possibly the remains of a furnace. The abrupt transition between the MSA and the Iron Age levels, without an apparent intervening LSA, would seem to indicate a significant occupational hiatus. However, two

Stratigraphic Profile of Test Pit 12

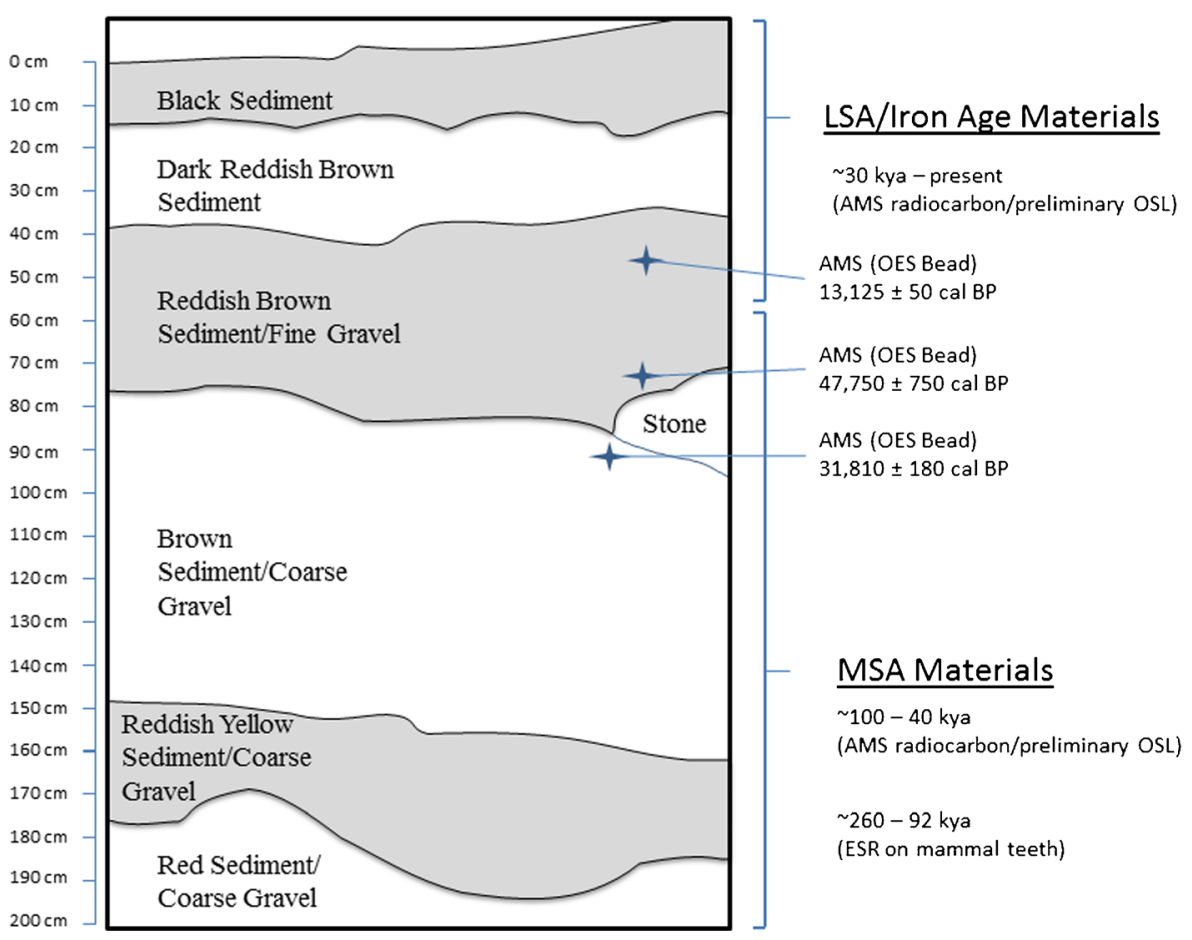

Fig. 4 Stratigraphic Profile of Test Pit 12 
ostrich eggshell beads directly dated with AMS radiocarbon point to a late LSA presence in this part of the site (Table 1). One is radiocarbon dated to $6465 \pm 33 \mathrm{BP}$ (OxA-27,629), the other to $13,125 \pm 50 \mathrm{BP}$ (OxA27,625) (Miller and Willoughby 2014). Although the beads were found in what appear to be Iron Age deposits, their radiocarbon age places them within the known chronology of the LSA. A possible explanation for the apparent absence of the LSA in this part of the site is that it is mixed with, and occluded by, Iron Age materials that infiltrated down through the sediment. It is also conceivable that occupation of this part of the site during the LSA was minimal or that the beads were curated from elsewhere and reused during the Iron Age. Due to the similarity in the lithics of the LSA and Iron Age further geoarchaeological work is planned to differentiate these assemblages and provide deeper insight into the formation of the sequence.

\section{Palaeoclimate of Eastern Africa}

Determining the effects of climate change on the behavioural variability of MSA humans has become a major focus of research in modern human origins studies. Large-scale climatic trends are thought to have spurred considerable changes in regional economic and settlement systems in many parts of the continent, resulting in the emergence of a range of new material behaviours, including stone technology (Marean et al. 2007; McCall 2007). While climate forcing remains a plausible hypothesis for technological change in eastern Africa, little direct supporting evidence has emerged (Blome et al. 2012; Douze and Delagnes 2016; Johnson et al. 2016; Tryon and Faith 2013). On a coarse scale, eastern African climate appears to have become wetter after $\sim 800,000$ years ago, succeeding a long period of aridity, but was increasingly subject to longer and more severe periods of drought lasting tens of thousands of years (Lyons et al. 2015). The span of time between 145,000 and 60,000 years ago, in particular, shows evidence of extreme aridification, responsible for a decline in the level of Lake Malawi and Lake Victoria (Lyons et al. 2015; Scholz et al. 2011). However, a seasonal supply of monsoon rains from the Indian Ocean may have mitigated this, and other climatological upsets to a degree, as a range of environmental proxies indicate that eastern Africa experienced a relatively muted response to climate change, especially in comparison to northern and southern Africa (Ambrose 1998; Basell 2008; Blome et al. 2012). The comparable stability of the region is further supported by low variation in site frequency between 150,000 and 30,000 (Basell 2008; Blome et al. 2012). Based on this observation some have argued that populations were able to moderate climate factors by relocating to different altitudes, or that they were buffered to an extent in some other way (Basell 2008; Blome et al. 2012; Pickford 1995). Nonetheless, it is important to recognize that large-scale climatic events had diverse local impacts, and different regions of eastern Africa experienced dissimilar and asynchronous climate regimes over their respective histories (Blome et al. 2012). The strategies adopted by human populations in response to climate change during the MSA are therefore likely to have been varied and highly dependent on existing local conditions.

With respect to the timeline of Magubike, a multiproxy approach derived from continental and oceanic cores shows that during MIS 4 eastern Africa experienced a transition from a wet period to a dry one beginning around 65,000 years ago (Blome et al. 2012). This trend is supported by water level proxies from Lake Malawi, which show a similar decline in temperature and moisture between 71,000 to 61,000 years ago (Lyons et al. 2015; Scholz et al. 2011). Both of these records reveal a picture of cooling climate in eastern Africa at the time when Magubike was first occupied, approximately 65,000 BP. More specific paleoenvironmental data for the Iringa region is unfortunately limited. Lake cores from the Eastern Arc Mountains, $\sim 40 \mathrm{~km}$ to the east of Magubike, show long-term climate stability dating back to at least $\sim 48,000 \mathrm{BP}$, but do not necessarily imply climate stability further back in time (Finch et al. 2009; Mumbi et al. 2008). Environmental analysis of Magubike and its surrounding topography is planned for the near future to extend this sequence further back into the MSA and to test the environmental hypotheses explored in this article.

\section{Lithic Analysis}

The following is an analysis and discussion of lithic technology, typology and raw material variability in the MSA levels at Magubike. In general, human cultures are responsive to a diverse range of physical and social conditions, and frequently arrive at a number of novel solutions to cope with them. One such set of consideration for Stone Age humans is the quality, abundance, 
availability and distribution of tool-stone in their homerange. In combination these factors are likely to inform not only immediate technological behaviours but also reflect broader patterns of land-use behaviour. Hunter/ gatherer populations are also highly influenced by the distribution and predictability of food and water resources, and changes to these variables are often reflected in terms of stone technology as well. Thus, by incorporating knowledge of the lithic resources of the Iringa highlands with MSA technology from the site it is possible to better understand how biotic and abiotic environmental forces and stone technology were integrated at Magubike (Table 2).

The first section is a break-down of the lithic raw materials found at the site, contextualized within a geological understanding of the Iringa landscape. These observations factor into discussions of availability, land-use and procurement behaviour. A typological analysis is also presented, with an emphasis on how the representation of different artefact types in the sequence changed by level, and what this might reflect in terms of adaptive behaviour. A technological analysis of the artefacts was further used to trace specific reduction pathways and reinforce the conclusions concerning raw material economy. Lastly, a means of measuring reduction intensity was deployed to quantify the extent to which different materials were reduced, and how reduction intensity varied by level. These data are developed into a discussion of probable causes.

\section{Raw Materials}

In Test Pit 12 small cobbles of quartz, and a range of metamorphic stones, formed the bulk of the lithic materials during the MSA $(47.1 \%, n=6311$ and $43.6 \%$, $n=5836$ respectively) (Figs. 5, 6). Vein quartz from decaying granites is ubiquitous on the modern surface around the rockshelter, and if the present distribution of quartz is similar to past conditions it would have been possible for MSA hominins to collect it in large quantities without expending much effort or going more than a few hundred meters from the shelter. However, local quartz is extant almost exclusively in the form of small rounded cobbles (between 3 and $6 \mathrm{~cm}$ in maximum dimension on average) and fractures unpredictably due to numerous internal fracture planes, creating a high proportion of shatter. Its value may therefore have been diminished to some extent by its relative resistance to shaping (Biittner 2011).

The other major source of lithic material used by Magubike hominins was metamorphic rock. This category encompasses an assortment of macroscopically identical material types that are generally fine to course-grained, dark in colour, and found in larger pieces than the local quartz. Like quartz, no primary sources for metamorphic stones are evident, and it is likely that they were collected in the form of rounded cobbles from nearby stream-beds or other secondary contexts.

Table 2 Tool type by Raw Material during the MSA

\begin{tabular}{|c|c|c|c|c|c|c|c|c|}
\hline & & & \multicolumn{5}{|c|}{ Raw Material Type } & \multirow[b]{2}{*}{ Total } \\
\hline & & & Quartz & Quartzite & Chert & Metamorphic & Other & \\
\hline \multirow[t]{9}{*}{ Tool Type } & Scraper & $\mathrm{n}$ & 132 & 18 & 22 & 66 & 7 & 245 \\
\hline & & $\%$ within Tool Type & $53.9 \%$ & $7.3 \%$ & $9.0 \%$ & $26.9 \%$ & $2.9 \%$ & $100.0 \%$ \\
\hline & & $\%$ within Raw Material & $36.1 \%$ & $56.3 \%$ & $44.9 \%$ & $62.9 \%$ & $77.8 \%$ & $43.7 \%$ \\
\hline & Blacked Pieces & $\mathrm{n}$ & 205 & 5 & 20 & 9 & 1 & 240 \\
\hline & & $\%$ within Tool Type & $85.4 \%$ & $2.1 \%$ & $8.3 \%$ & $3.8 \%$ & $.4 \%$ & $100.0 \%$ \\
\hline & & $\%$ within Raw Material & $56.0 \%$ & $15.6 \%$ & $40.8 \%$ & $8.6 \%$ & $11.1 . \%$ & $42.8 \%$ \\
\hline & Points & $\mathrm{n}$ & 29 & 9 & 7 & 30 & 11 & 76 \\
\hline & & $\%$ within Tool Type & $38.2 \%$ & $11.8 \%$ & $9.2 \%$ & $39.5 \%$ & $1.3 \%$ & $100.0 \%$ \\
\hline & & $\%$ within Raw Material & $7.9 \%$ & $28.1 \%$ & $14.3 \%$ & $28.6 \%$ & $11.1 \%$ & $13.5 \%$ \\
\hline \multirow[t]{3}{*}{ Total } & & $\mathrm{n}$ & 366 & 32 & 49 & 105 & 9 & 561 \\
\hline & & $\%$ within Tool Type & $65.2 \%$ & $5.7 \%$ & $8.7 \%$ & $18.7 \%$ & $1.6 \%$ & $100.0 \%$ \\
\hline & & $\%$ within Raw Material & $100.0 \%$ & $100.0 \%$ & $100.0 \%$ & $100.0 \%$ & $100.0 \%$ & $100.0 \%$ \\
\hline
\end{tabular}




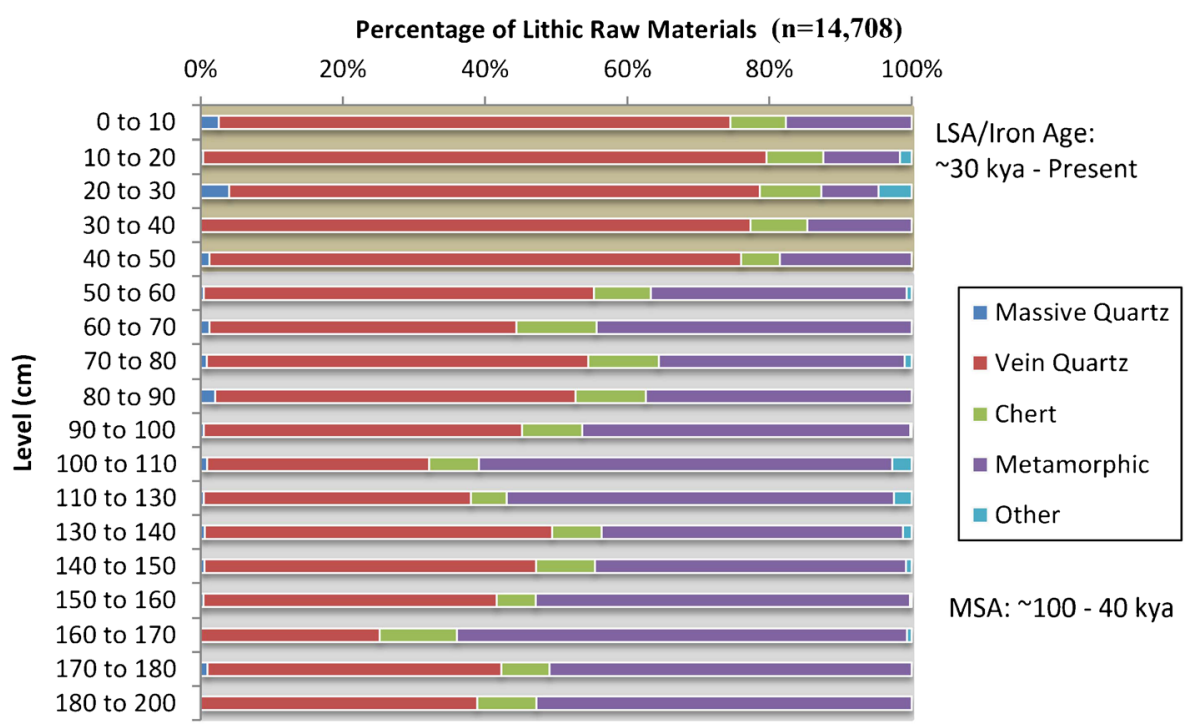

Fig. 5 Percentage of Lithic Raw Materials by Level (all images in full color online)

Small quantities of chert were also present in the MSA assemblage (chert: $7.6 \%, n=1119$ ). Chert appears to have been present in the form of small weathered pebbles that likely eroded and were transported from their source locations. Although no chert sources are recorded on local geological maps, a study of the available information indicates that they may have derived from limestone deposits approximately $50 \mathrm{~km}$ from the Magubike site, and then been relocated by alluvial action. Further survey is planned to confirm these suspicions.
Despite the general pattern described above, the proportion with which these different materials were utilized during the MSA at Magubike shows evidence of change by level. While chert remained a consistently minor part of the assemblage, quartz increased in proportion at the expense of metamorphic stones. The change in raw material preference appears to have been gradual, taking place over several excavation levels, although a more dramatic, step-wise, increase in quartz is visible between levels $40-50$ and $50-60 \mathrm{~cm}$, potentially corresponding to the transition to the LSA (Figs. 5 and 6).

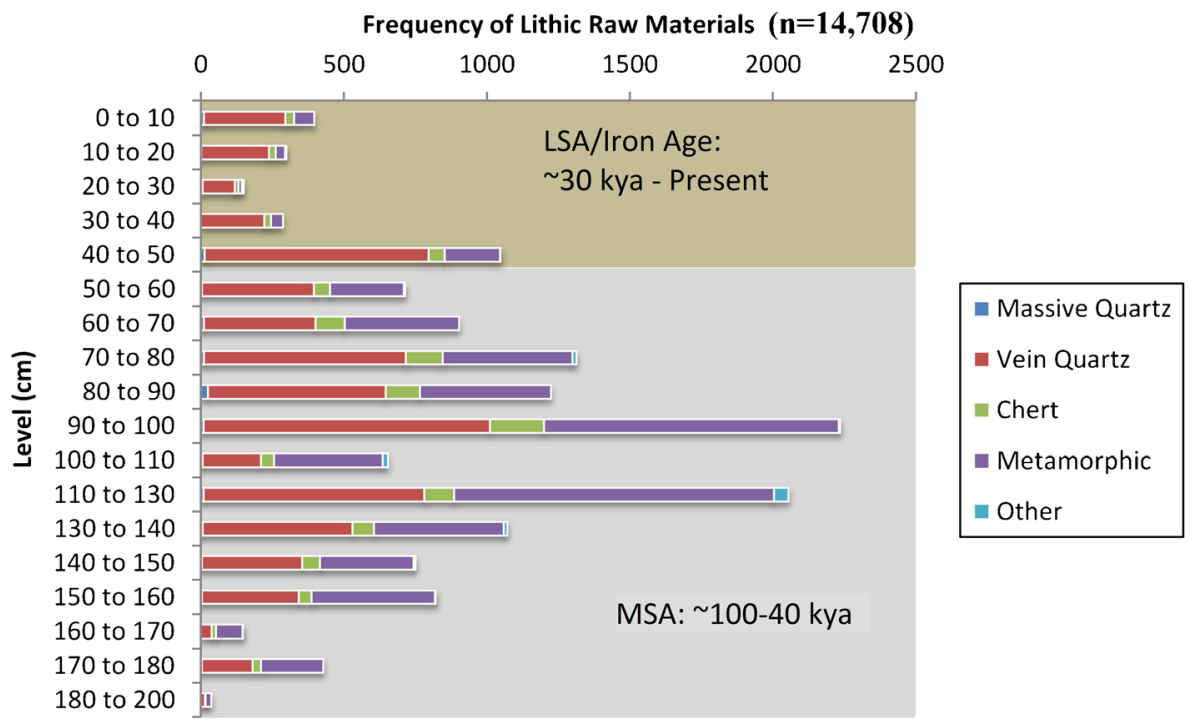

Fig. 6 Frequency of Lithic Raw Materials by Level 
Lithic Typology and Technological Organization

For the sake of comparability, lithic artefacts were classified according to Mehlman's (1989) typology for Mumba and Nasera, which includes four general categories: trimmed (retouched) pieces, cores, debitage and non-flaked stone (see Table 3). For the purpose of calculating frequencies and proportions all collected pieces were tabulated. As at other MSA sites, very few trimmed pieces were recovered from the Magubike site $(5.3 \%$, $n=797$ ) (Barham 2002; Schoville 2010). Those flakes that were retouched were generally lightly transformed into an assortment of scrapers, points and backed pieces. The degree of retouch intensity was, in most cases, very minor, and most pieces were not retouched beyond the margins of the tool. However, materials such as chert appear to have been selected for more intensive modification relative to more common and less workable materials like quartz. It is likely that most tools were used expediently with little or no time invested in secondary modification, and edge damage, possibly attributable to utilization, was noted on many unretouched specimens $(n=415)$. While retouched tools remained a minor part of the MSA stone artefact assemblage, they did increase slightly in proportion and frequency through time (Figs. 7, 8). For the most part, this trend was generated by the frequency of backed pieces, which became increasingly common while points and scrapers were gradually phased out (Figs. 9, 10; Table 4). Unlike backed tools from later periods that are typically produced from blades and bladelets, most of the backed segments from the Magubike site appear to have been opportunistically created from large conveniently shaped flakes (Barham 2002). The backed pieces from Magubike also declined in size during the MSA, showing continuity with smaller backed tools found in the subsequent LSA and Iron Age.

Scrapers from Magubike were predominantly created from quartz $(n=132,54 \%)$ and metamorphic stones $(n=66,30 \%)$. Although too few scrapers were recovered in each level to perform a more formal statistical analysis they appear to show little variation over time. This trend is mirrored by points, which were uniformly made from quartz and metamorphic stones in each level ( $n=29$ and $n=30$, respectively). Lastly, backed pieces were made almost exclusively using quartz $(n=205$, $85 \%$ ). This tendency does not seem to have changed with site level. For greater detail regarding artefact types and raw material see Table 2.
Core technology at the Magubike site was also relatively uniform chronologically. Bipolar cores comprised just over $85 \%(n=489)$ of all cores in Test Pit 12. In this study bipolar cores are defined as having been reduced using the "hammer-and-anvil" technique in contrast to cores that were exploited from two opposing platforms. Many flakes also show evidence of having been produced using bipolar technology, such as battering on opposite ends in conjunction with overlapping step fractures and wedging initiations. It is clear that this method was deployed in response to the properties of local lithic materials, particularly quartz. Since Iringa quartz is found in the form of small round pieces, bipolar reduction may have been one of few viable strategies available to MSA hominins at the Magubike site. Most other cores appear to have been worked opportunistically from multiple platforms, or peripherally in a slightly more patterned manner. Although no classic Levallois cores were found, some flakes show evidence of Levallois-like core preparation, including multi-faceted platforms and radial or converging dorsal flake scars (Van Peer 1992). It is possible that Levallois cores were further worked using other methods, such as bipolar, after they had been otherwise exhausted. Middle Stone Age points at Magubike, in particular, seem to have been primarily produced using Levallois methods. These points were mostly made by removing flakes from adjacent platforms of the core, the scars of which converge to produce a triangular outline. A small triangular flake was then sometimes struck from the proximal end of the point to thin the base before the Levallois point was removed. Most points also showed evidence of platform preparation such as trimming and faceting, and some were characterized by modifications to the base subsequent to removal. Any basal modification at Magubike was in the form of flake removals to the dorsal and ventral surface, initiated from the platform, after the piece was struck from the core. These modifications were presumably to facilitate hafting, although the function of MSA points from Magubike remains unknown.

The MSA occupants of the Magubike site also produced a large number of linear flakes that were classified as blades $(n=298)$. However, no blade cores have been found to date, and it is unclear if the behaviour was intentional (i.e., simply the product of core preparation) or if blades were transported to the site from elsewhere. Unlike trimmed pieces, which demonstrated differences in proportional representation through time, bipolar, 


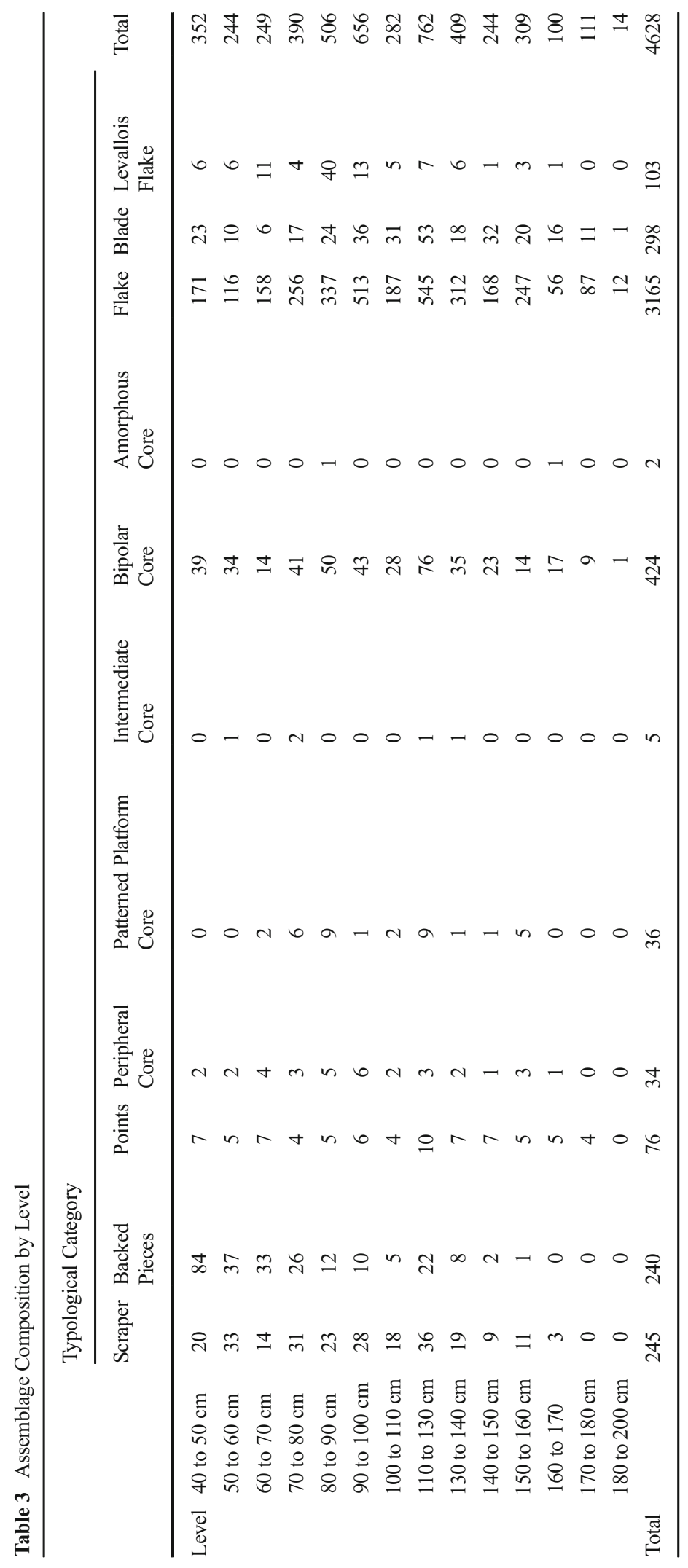




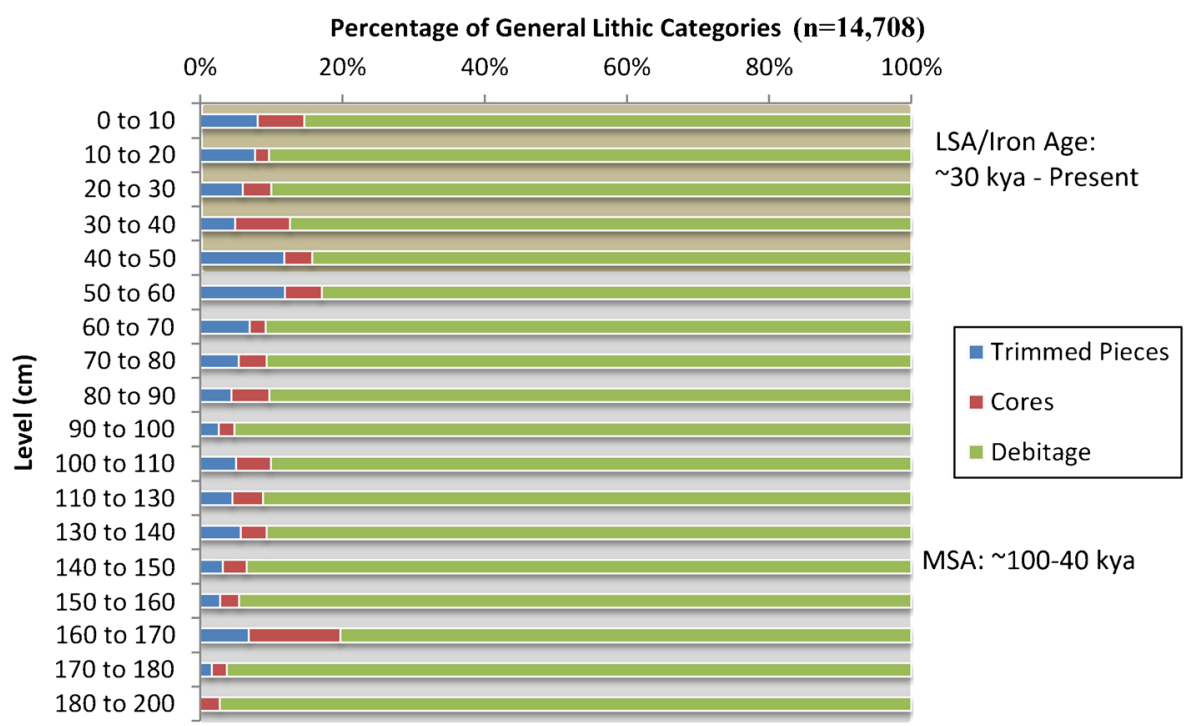

Fig. 7 Percentage of General Lithic Categories by Level

multiple platform and peripheral/radial cores were randomly distributed throughout the sequence (Figs. 11, 12). We conclude that although the end products of the reduction sequence appear to have exhibited change over time, the methods of producing flake blanks remained relatively constant. Nevertheless, raw material was significantly related to core type, suggesting different reduction pathways $\left(\chi^{2}=42.254(\mathrm{df}=4)\right.$, $p<0.0001)$. Specifically, quartz was the favoured material for bipolar and peripheral/radial cores while metamorphic stones were preferred for multi-platform and Levallois-like cores. Although chert cores were rare, they were most likely to be peripherally flaked. More detail on the raw material composition of cores by level is shown in Table 5.

As with most lithic assemblages, debitage formed the single largest category of stone artefacts $(91.0 \%$, $n=12,189)$. Most of this material was composed of flake fragments and angular shatter. However, a large number of whole flakes $(n=3165)$ and blades $(n=298)$ were also found. It is probable that many of these were used as expedient tools and then discarded shortly afterwards. As noted earlier, a total of 415 of these flakes and blades exhibited signs of utilization. The distribution of

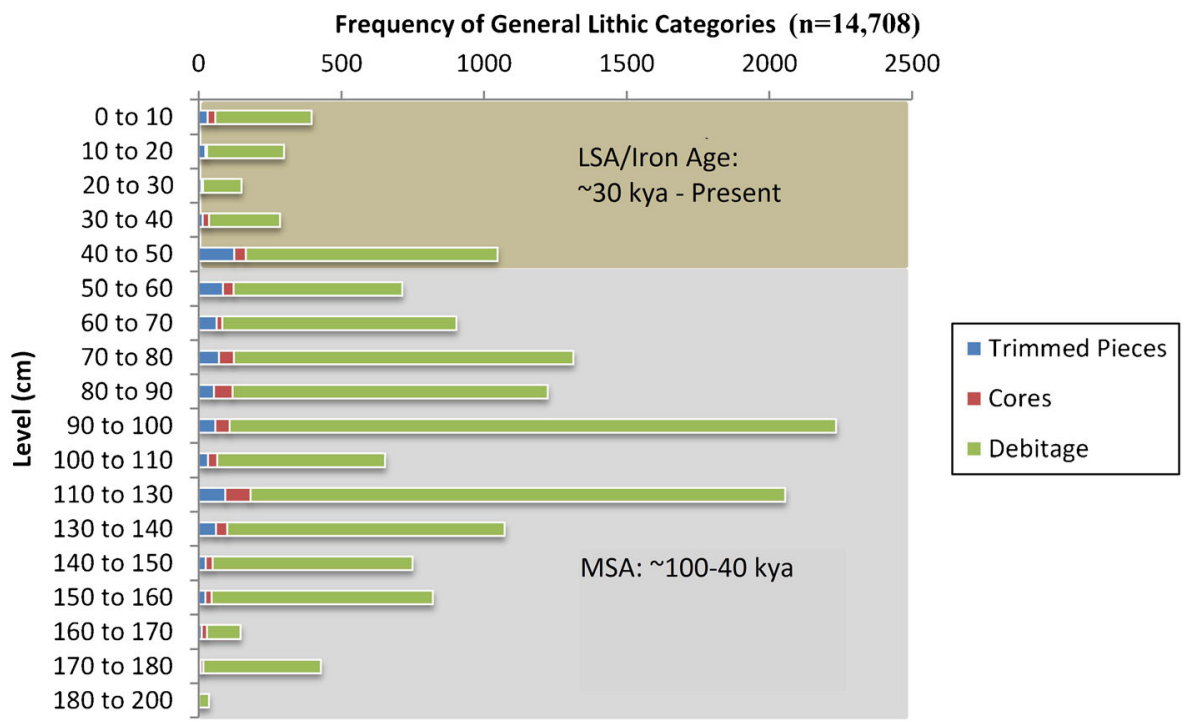

Fig. 8 Frequency of General Lithic Categories by Level 


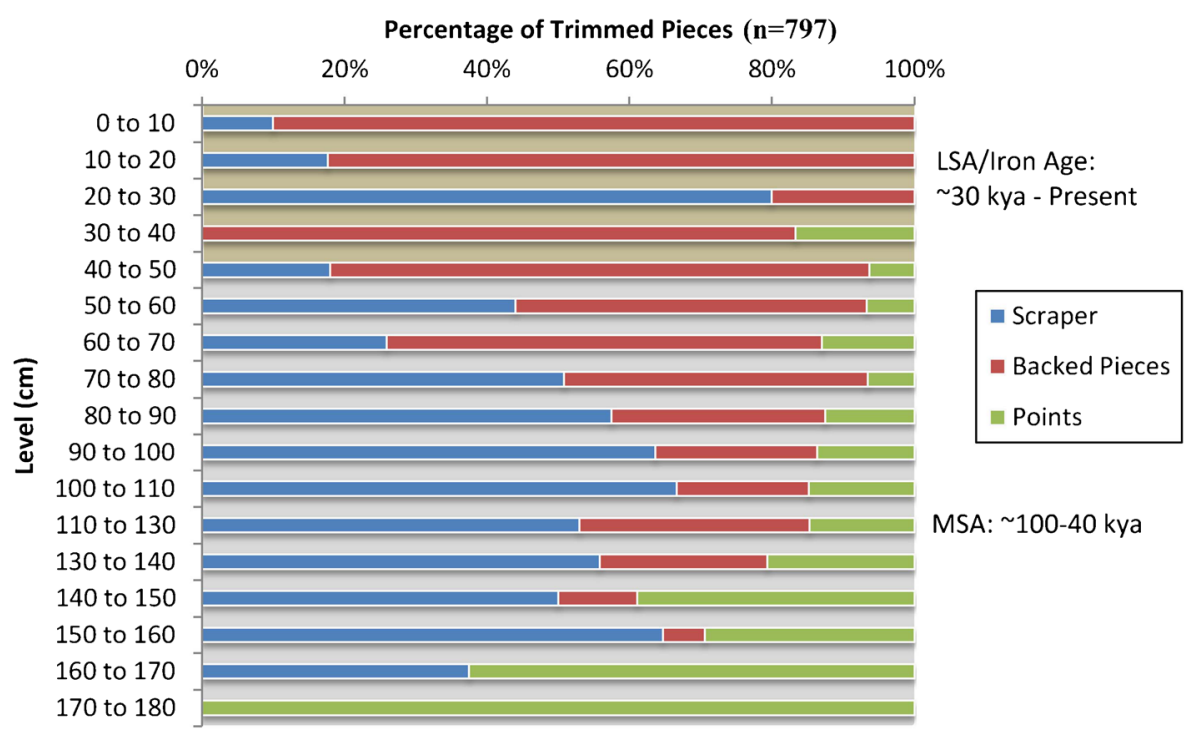

Fig. 9 Percentage of Trimmed Pieces by Level

cortex on these flakes indicates that all stages of reduction were practiced in the rockshelter (Toth 1987). Given the profusion of stones readily available within a few kilometres of the shelter, the cost of transporting unmodified cobbles would have been relatively low, and extensive field processing may not have been required. Very few non-flaked stones were collected during excavation, many of which were not modified; they are therefore not described in any detail here $(n=4)$.

In summary, there appear to have been several different operational chains active at Magubike, which were somewhat material dependent. Few of the end-products of these sequences were comprehensively retouched, which is typical of other Tanzanian assemblages; although, pieces possibly bearing damage as a result of utilization suggest that the inhabitants of Magubike were manipulating different reduction sequences to produce varied blank or edge morphologies to use as tools. By far the most common chain involved the collection of small quartz cobbles and pebbles, abundant in the Iringa landscape, for transformation into expedient tools and

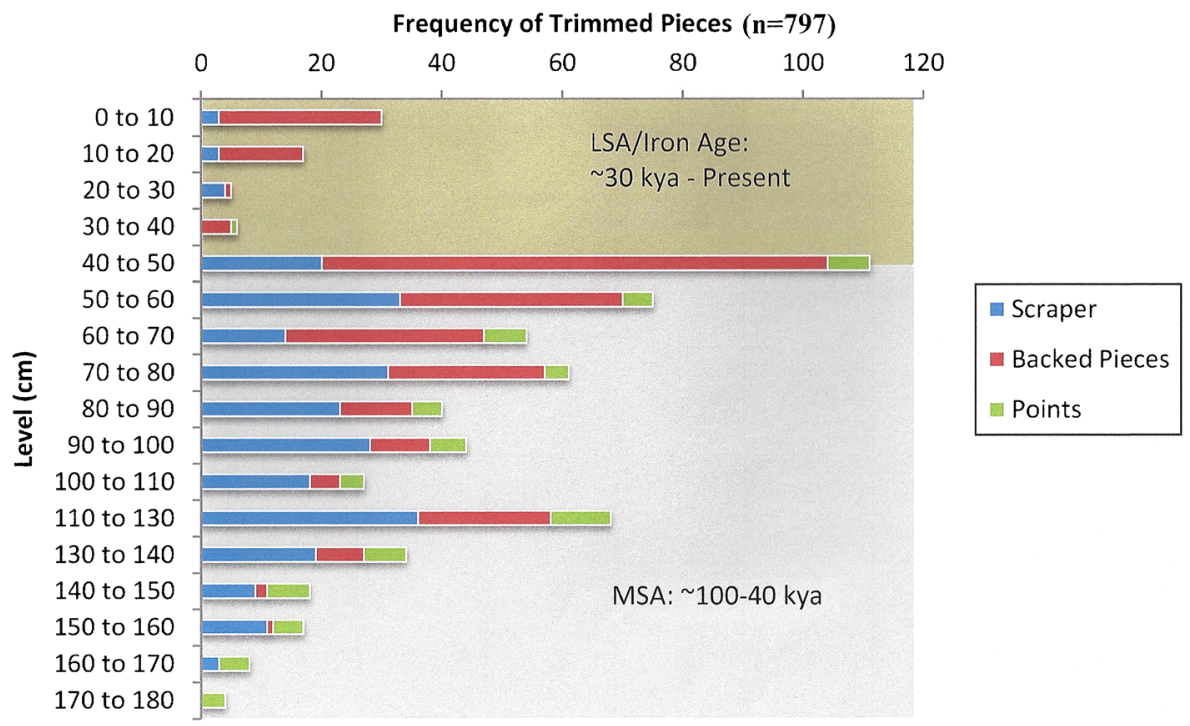

Fig. 10 Frequency of Trimmed Pieces by Level 
Table 4 Tools by Raw Material and Level

\begin{tabular}{|c|c|c|c|c|c|c|}
\hline & & \multicolumn{4}{|c|}{ Raw Material } & \multirow[t]{2}{*}{ Total } \\
\hline & & Quartz & Chert & Metamorphic & Other & \\
\hline \multirow[t]{13}{*}{ Level } & 40 to $50 \mathrm{~cm}$ & 95 & 5 & 11 & 0 & 111 \\
\hline & 50 to $60 \mathrm{~cm}$ & 51 & 7 & 16 & 1 & 75 \\
\hline & 60 to $70 \mathrm{~cm}$ & 33 & 6 & 15 & 0 & 54 \\
\hline & 70 to $80 \mathrm{~cm}$ & 34 & 10 & 13 & 4 & 61 \\
\hline & 80 to $90 \mathrm{~cm}$ & 27 & 7 & 6 & 0 & 40 \\
\hline & 90 to $100 \mathrm{~cm}$ & 25 & 6 & 13 & 0 & 44 \\
\hline & 100 to $110 \mathrm{~cm}$ & 16 & 1 & 10 & 0 & 27 \\
\hline & 110 to $130 \mathrm{~cm}$ & 32 & 5 & 28 & 3 & 68 \\
\hline & 130 to $140 \mathrm{~cm}$ & 25 & 1 & 8 & 0 & 34 \\
\hline & 140 to $150 \mathrm{~cm}$ & 11 & 0 & 7 & 0 & 18 \\
\hline & 150 to $160 \mathrm{~cm}$ & 12 & 0 & 4 & 1 & 17 \\
\hline & 160 to $170 \mathrm{~cm}$ & 3 & 1 & 4 & 0 & 8 \\
\hline & 170 to $180 \mathrm{~cm}$ & 2 & 0 & 2 & 0 & 4 \\
\hline Total & & 366 & 49 & 105 & 9 & 561 \\
\hline
\end{tabular}

backed pieces. Cortex on flakes and cores confirms that cobbles were brought to the site with little prior processing, and that the majority of reduction took place within the rockshelter. Most quartz cores were subsequently reduced using bipolar methods in order to achieve viable blanks, although a few of the larger quartz pieces were evidently selected for radial or opportunistic flaking. In a similar fashion, larger weathered cobbles of metamorphic materials were brought in a raw form to the site. From there they were transformed into blanks using either a casual, un-patterned approach or a more refined radial/Levallois method. Most metamorphic flakes were likely used expediently given a similar lack of formal tools. Conversely, some metamorphic blanks were transformed into scrapers and points with only a few used to create backed pieces $(n=9,3.8 \%)$. Lastly, Iringa chert is found sporadically in the form of rounded cobbles no larger than $8-10 \mathrm{~cm}$. These pieces were most often reduced bipolarly to produce sharp flakes and small tools, but were more likely than either quartz or metamorphic cores to show

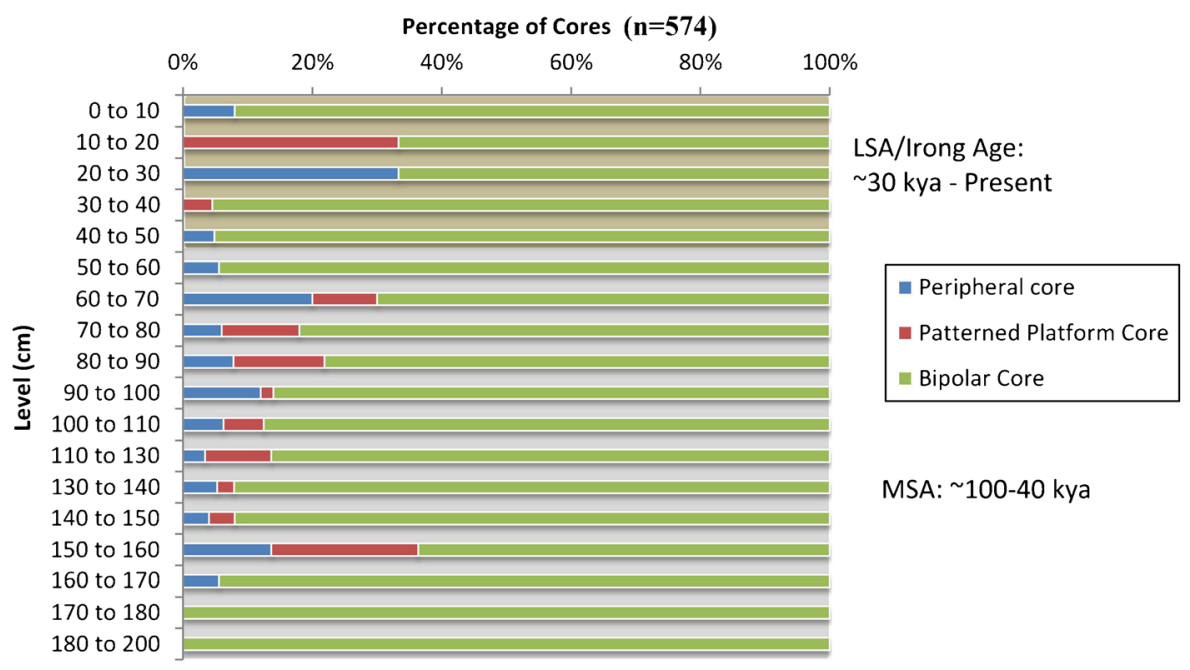

Fig. 11 Percentage of Cores by Level 


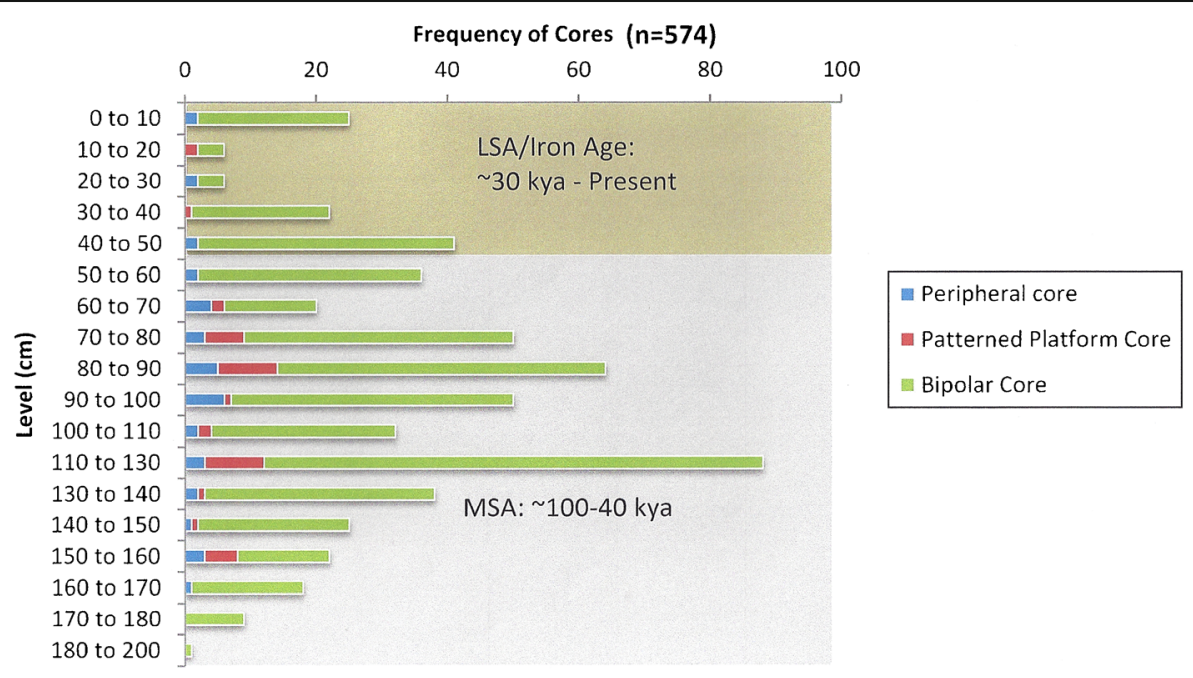

Fig. 12 Frequency of Cores by Level

signs of meticulous radial flaking (17\% compared to $5 \%$ for quartz and $4 \%$ for metamorphic stones). The majority of formal chert tools were scrapers and backed tools (37\% and 30\% respectively).

\section{Lithic Reduction Intensity}

During the Late Pleistocene fluctuations in environmental and demographic pressure appear to have had significant impacts on the settlement behaviour of MSA humans across Africa (Blome et al. 2012; Lane et al. 2013; McCall 2007). The cascading effects of this shift likely transformed the ways in which early humans organized their subsistence strategies, social networks, and technology. If true, many of the choices made by MSA hominins would have been subsequently manifest in their use of lithic materials. In particular, the intensity with which materials were reduced is intimately linked to raw material requirements, availability and quality, and thus provides an effective means of recognizing

Table 5 Cores by Raw Material and Level

\begin{tabular}{|c|c|c|c|c|c|c|}
\hline & & \multicolumn{4}{|c|}{ Raw Material } & \multirow[b]{2}{*}{ Total } \\
\hline & & Quartz & Chert & Metamorphic & Other & \\
\hline \multirow[t]{14}{*}{ Level } & 40 to $50 \mathrm{~cm}$ & 37 & 0 & 4 & 0 & 41 \\
\hline & 50 to $60 \mathrm{~cm}$ & 25 & 3 & 9 & 0 & 37 \\
\hline & 60 to $70 \mathrm{~cm}$ & 10 & 7 & 3 & 0 & 20 \\
\hline & 70 to $80 \mathrm{~cm}$ & 41 & 3 & 5 & 3 & 52 \\
\hline & 80 to $90 \mathrm{~cm}$ & 33 & 13 & 19 & 0 & 65 \\
\hline & 90 to $100 \mathrm{~cm}$ & 20 & 16 & 14 & 0 & 50 \\
\hline & 100 to $110 \mathrm{~cm}$ & 15 & 3 & 8 & 6 & 32 \\
\hline & 110 to $130 \mathrm{~cm}$ & 41 & 5 & 40 & 3 & 89 \\
\hline & 130 to $140 \mathrm{~cm}$ & 24 & 2 & 12 & 1 & 39 \\
\hline & 140 to $150 \mathrm{~cm}$ & 11 & 5 & 9 & 0 & 25 \\
\hline & 150 to $160 \mathrm{~cm}$ & 10 & 3 & 9 & 0 & 22 \\
\hline & 160 to $170 \mathrm{~cm}$ & 5 & 3 & 10 & 1 & 19 \\
\hline & 170 to $180 \mathrm{~cm}$ & 6 & 0 & 3 & 0 & 9 \\
\hline & 180 to $200 \mathrm{~cm}$ & 0 & 0 & 1 & 0 & 1 \\
\hline Total & & 278 & 63 & 108 & 14 & 501 \\
\hline
\end{tabular}


changes in mobility, home-range size, trade, raw material preferences and transport (Barut 1994; Dibble et al. 2005; Marwick 2008). Archaeological and ethnographic research has demonstrated that humans largely make cost-effective decisions about lithic raw material procurement (Andrefsky 2005; Bamforth 1986; Barut 1994; Bicho 2002; Gould and Saggers 1985; McCall 2007). This tendency usually results in the preferred use of local materials over those located more distantly, especially if raw material quality is held constant. Because of this relationship, higher procurement and transportation inputs are frequently correlated with higher reduction intensity, as foragers implement practices to maximize high quality materials obtained at greater cost (Marks et al. 1991; Marwick 2008).

Nevertheless, it is worth noting that the raw material quality requirements of certain technological approaches can significantly alter the relationship between procurement and mobility (Bamforth 1986; Gould and Saggers 1985). In the event that material requirements are not met locally, groups may move further in search of them or realign their reduction strategies to accommodate existing resources. On the other hand, if materials quality requirements are low, or raw materials are ubiquitous, evidence of a raw material economy may be poorly developed or non-existent (Barut 1994; Marks et al. 1991). Even so, source-distances of under $2 \mathrm{~km}$ have been shown to have significant impacts on the raw material content of assemblages (Marks et al. 1991). As demonstrated by Marks et al. (1991), even minor differences in the way that raw materials are distributed can influence the manner and frequency with which they are collected, and how they are transformed within assemblages.

Raw material constraints are also associated with the adoption of different technological approaches. Levallois-like reduction strategies, for instance, are unlikely to be practiced in regions where nodule size is small or low quality, and quantities of tool-stone are limited (Brantingham and Kuhn 2001; Sandgathe 2004; Van Peer 1992). The change to backed tool assemblages during the Howiesons Poort, on the other hand, is sometimes associated with a program of intensification (Eren et al. 2008; Lombard 2005). However, rather than altering their technological approaches, prehistoric people may have simply implemented strategies to extend the use-life of cores (Marks et al. 1991). In practice, both of these approaches may have been adopted to gain the most usable materials from a finite quantity of stones.
Because of its relevance to a number of common archaeological questions a series of different metrics have been developed and deployed to measure reduction intensity in stone tool assemblages (Blades 2003; Clarkson 2010; Clarkson and Hiscock 2008; Henry 1989; Hiscock and Clarkson 2005; Hiscock and Tabrett 2010; Marwick 2008). However, not all of these methods are applicable to all types of lithic assemblages. Techniques that focus on tool retouch, for instance, may be inappropriate for MSA artefacts, which often feature absent or minimal retouch. Due to a general lack of formal tools, approaches targeted at core rather than tool reduction may be more practicable. Conventional wisdom and experimentation show that as core reduction intensity increases core mass and the amount of core cortex generally decline (Henry 1989; Marks et al. 1991; Newcomer 1971). Simultaneously, as cores are reduced, the number of flake scars on their surface increases as more material is removed. Nevertheless, certain considerations prohibit these generalizations from being truly predictive. One important factor is nodule size, which significantly informs the size of the core at discard. In short, nodules that were small to begin with will tend to be small when exhausted. Flake scar count is also somewhat dependent on variation in core size. In general, smaller cores will tend to have fewer flake scars, as a result of their reduced surface area. Finally, cortical surface is also sensitive to factors unrelated to reduction intensity, and some technological sequences, such as Levallois, may leave cortex until late in the reduction process (Van Peer 1992).

In an attempt to resolve some of these issues, Clarkson (2013) introduced a technique to measure core reduction in MSA assemblages using 3D scanning technology. His technique relies on the assumption that as core mass decreases, the ratio of flake scars to remaining surface area will increase. To quantify this relationship, flake scar count is standardized against core surface area to produce a new value called the Scar Density Index (SDI). In other words, SDI represents the ratio of flake scars to core surface area, or the number of flake scars per unit squared of surface area. Although Clarkson (2013) advocated the use of a 3D scanner to achieve the most accurate measurements of surface area, he noted a strong and significant correlation between scanner and calliper derived measurements $(r=0.949$, $p=0.0001$ ). Lin et al. (2010) also commented that although the error-range of non-scanning methods can 
potentially be considerable for individual artefacts, this error was substantially mitigated as sample size increased. While 3D scanning results are undoubtedly more accurate, the cumulative time to scan individual artefacts can be prohibitive for very large samples. Here it is shown that a modified version of SDI, based on calliper measurements, can still effectively detect diachronic differences in reduction intensity as well as differences in reduction intensity between different raw material types.

Flake Scar Density Index (SDI) Methods and Results

To measure relative reduction intensity, the SDI of 501 cores was calculated, as per Clarkson (2013). The geometric solid that produced the best approximation of surface area was a rectangular prism, the surface area of which is simple to calculate and requires only a few basic measurements that are commonly recorded by lithic analysts (length, width and thickness). Core length in this study was obtained by measuring the maximum dimension of the core. Core width was defined as the second longest dimension perpendicular to the length, and core thickness was defined as the third longest dimension perpendicular to the length (Andrefsky 2005). All cores were measured in this way and the data were entered into an IBM SPSS Statistics database for manipulation.

The compiled results (Figs. 13, 14) show that there was a significant difference in the way in which raw materials were reduced during the MSA at Magubike (ANOVA, $\mathrm{df}=3, \mathrm{~F}=8.713, p=0.0001$ ). Chert appears to have been most intensively used and conserved relative to other materials, despite forming only a small percentage of the MSA assemblage (Fig. 12). The next most reduced material was quartz, followed by metamorphic and other stones (Fig. 5). Quartz was significantly more reduced than metamorphic stones $(t=2.472, \mathrm{df}=419, p=0.014)$, while metamorphic and other stones did not differ in the extent to which they were utilized $(t=-.364$, df $=118, p=0.717)$. These differences suggest that a pronounced raw material economy existed during the MSA, which was responsive to factors such as lithic availability, abundance and quality. Reduction intensity also varied by level during the MSA (Fig. 14). A significant increase in SDI for all materials was observed from the oldest layers through to the youngest $\left(\mathrm{r}_{\mathrm{s}}=-0.253, \mathrm{df}=12, p=0.0001\right)$. This trend suggests that the Magubike hominins were making more conservative use of stone resources at the end of the MSA relative to the beginning.

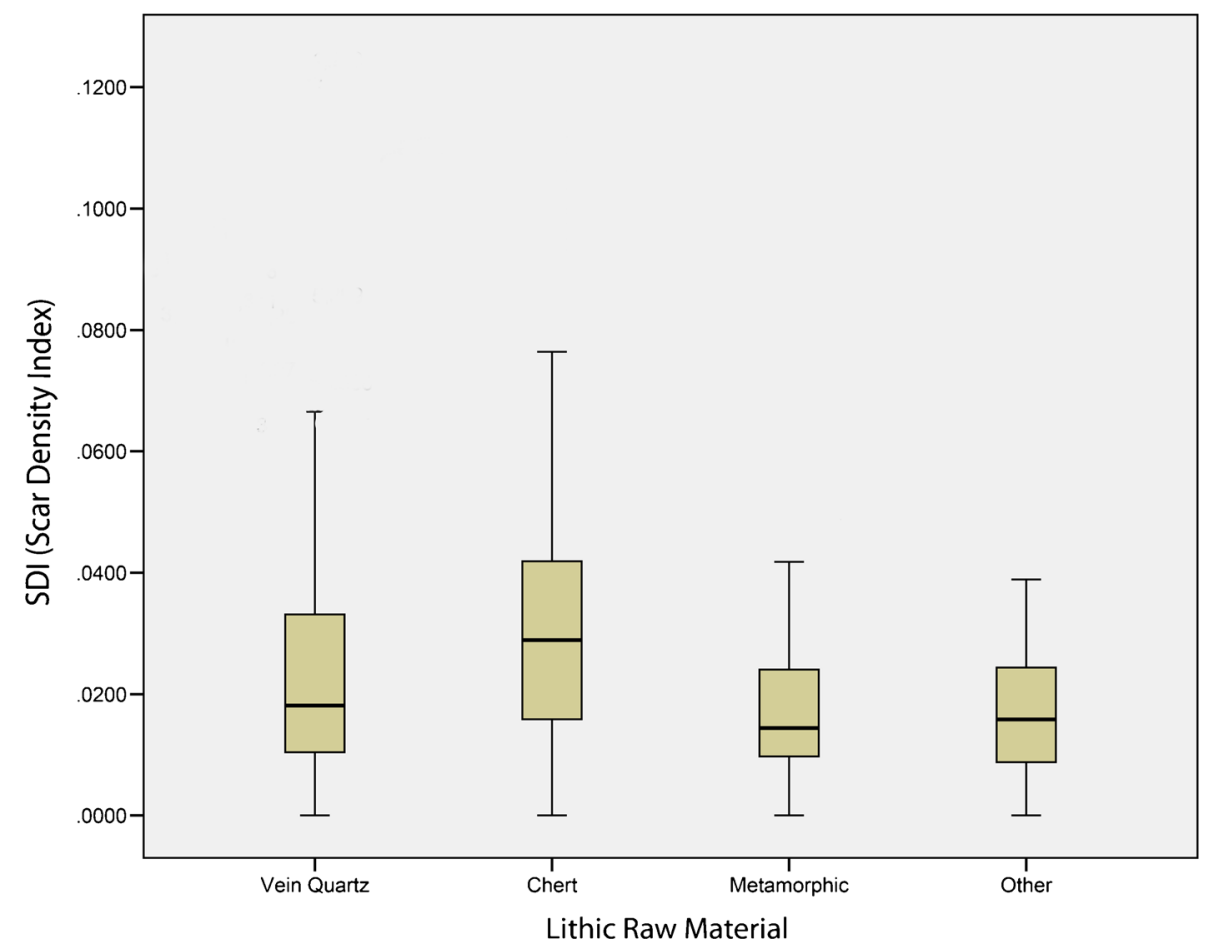

Fig. 13 Differences in SDI according to Raw Material 


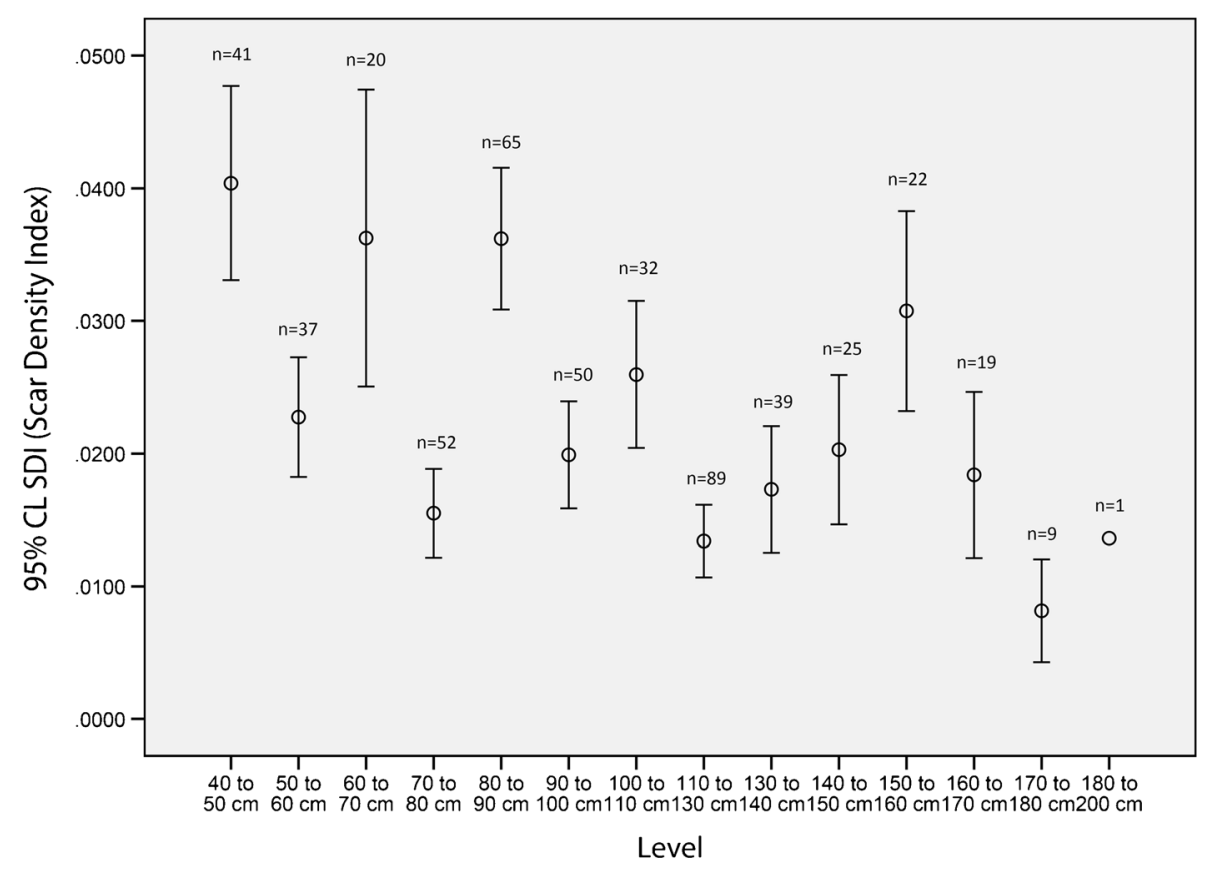

Fig. 14 Differences in SDI according to Level with 95\% confidence level (CL) bars

\section{Discussion}

The analysis presented here is intended to contribute to the rapidly growing body of information available regarding the ways in which early human foragers met the demands of local environmental conditions during the MSA in eastern Africa. To date, the archaeological information available for eastern Africa indicates a general pattern of adaptation marked by gradual change, high diversity and a relative lack of clearly circumscribed industries such as the Howiesons Poort or Still Bay (Tryon and Faith 2013). This pattern is reinforced at Magubike, which exhibits a gradual unidirectional change in raw material preference, typology and reduction intensity. Here we explore several possible causes including the hypothesis that these differences were due to transformations to the environmental context of Magubike during the Late Pleistocene.

On the basis of SDI measurements, several conclusions can be drawn regarding raw material economy at Magubike during the MSA. Overall, chert was reduced much more intensely than other materials, suggesting that attempts were made to maximize this resource. Furthermore, it was far more likely to be flaked using economical strategies and modified by retouching. Despite an apparent preference for chert, its limited frequency in the MSA levels at Magubike is an indication that it was less abundant locally than other materials, or was more costly to access. Survey of the area confirms this assumption, and discrete chert sources have yet to be located in the area surrounding Magubike. Rather, chert is this region appears to be present as small isolated nodules, which likely formed as precipitates within a chalky matrix that was subsequently eroded. Given the unpredictable and patchy distribution of chert, it is probable that nodules of pebble chert were simply collected as they were encountered on the landscape during the course of other activities rather than targeted for acquisition. Early survey work shows that they may have been recoverable from stream beds and other catchments alongside other lithic materials. This theory of lithic access is supported by water rounded cortex on chert flakes and cores. Quartz, on the other hand, appears to have been a staple stone resource during the MSA and LSA. Like chert, non-centralized concentrations of quartz are scattered unpredictably across the Iringa landscape. It is therefore probable that this resource was also exploited as it was encountered. Unlike chert, however, quartz is much more abundant. It is likely for this reasons that quartz was reduced less intensively. Metamorphic and other stones, on the other hand, were the least intensively reduced materials at Magubike. The restricted degree to which metamorphic stones were reduced is likely due to their limited 
knapping quality, although they may have been preferred from some tasks requiring larger tools.

Reduction intensity during the MSA showed significant diachronic variation as indicated by an overall increase in SDI values between the first occupation of the site and the beginning of the LSA (estimated to be a minimum of 65,000 to 40,000 years). It is possible to speculate that this pattern parallels a transition from warm to cold climate during MIS 4 (Blome et al. 2012; Lyons et al. 2015; Scholz et al. 2011). It may even be that the highlands around Magubike were first occupied by populations tracking steep gradients in altitude in seek of habitable conditions, as per the hypothesis of several scholars (Ambrose 1998; Basell 2008). Although it is currently not possible to convincingly align the climate record of eastern Africa with the chronology of the site, we are working to clarify the paleoenvironmental context and age of cultural deposits at Magubike in order to test this hypothesis. In the interim, patterns visible in the lithic record of Magubike demonstrate that a significant shift occurred during the MSA, which is at least consistent with adaptation to decreased environmental productivity (Clarkson 2013; McCall 2007). If the environment around Magubike became less dependable, foragers would have needed to travel larger distances in search of food and water. The rise in reduction intensity at Magubike in the MSA levels may thus be one symptom of the adoption of more mobile life-styles, and a greater reliance on projectile weapons, to track more widely distributed resources. Uncertain access to lithic materials as a result of larger home ranges would have encouraged conservation behaviour, reflected in a rising SDI.

A shift to more arid open landscapes during the Middle to Late Pleistocene is also commensurate with alterations to the tool-kit of MSA foragers at Magubike. Most types of retouched pieces were abandoned or phased out over time, resulting in a reliance on a fairly uniform selection of backed pieces, which presumably expanded to fill the roles of other tool types. The increased reliance on functionally generalized tools may indicate that the distribution of resources became less predictable and increasingly dispersed. Populations might therefore have adapted by creating tools that could be easily suited to a number of different extraction activities that could not be anticipated ahead of time. The increase in the proportion of backed pieces manufactured during the MSA may also reflect a more mobile life-style, as travel distances between resources patches increased, necessitating more portable tools, and the more careful conservation of stone resources. A preference for backed tools may also have been responsible for the gradual transition to quartz during the MSA levels $\left(\chi^{2}=32.124, \mathrm{df}=1, p=0.0001\right)$. Although the small natural size of Iringa quartz limits its usefulness for manufacturing tools such as Levallois points or bifaces, it may have been conducive to the production of small backed segments. Replication experiments using Iringa quartz show a tendency for small cobbles to break into wedge-like slices when percussed on an anvil due to natural fracture planes within their structure (i.e., with a single cortical surface and two ventral surfaces that converge to a point). These pseudo-backed pieces appear in the Magubike assemblage with and without further retouching in great numbers $(n=240)$. Finally, chert appears to have been used more flexibly than either quartz or metamorphic stones. Its superior flaking properties meant that it was equally well suited to the production of a number of different shapes, and was often transformed into scrapers and backed pieces. However, the small natural cobbles of Iringa chert are unsuitable for Levallois methods of reduction because of their size, and consequently, very few points were made using chert $(n=7)$.

While the observed increase in reduction intensity and small backed tools indicates an escalation in residential or logistical mobility, a lack of retouched tools overall during the MSA at Magubike might point to the presence of a relatively sedentary population (Parry and Kelly 1987). Mobile peoples are predicted to carry a small tool kit of carefully prepared tools to manage the risk of uncertain lithic availability and the high cost of tool-failure. Sedentary foragers on the other hand are generally more confident of nearby lithic sources and therefore invest comparatively little time producing highly refined tools, given that the cost of tool-failure and replacement is generally low. Nevertheless, it is important to be aware of factors capable of disrupting the basic assumption that mobile peoples manufacture formal tools while sedentary peoples produce informal tools. One such factor is the abundance of local stones. If local stones are of sufficient quality and abundance, both mobile and sedentary groups can exhibit a sedentary-like pattern of raw material usage, characterized by informal tools with little retouch (Gould 1980). The unpredictable access to lithic materials usually experienced by mobile groups may thus have been mitigated to a large extent by the ubiquity of quartz around 
Magubike, resulting in an assemblage more typical of sedentary groups. What is more, the frequency and proportion of retouched tools does appear to increase through time despite possible mitigating factors. Alternately, the lack of retouched tools at Magubike may be related to a dearth of high-quality materials, such as chert, in the environment causing a realignment of technological approaches (Tryon and Faith 2013).

\section{Conclusions}

To understand the full spectrum of human adaptation during the MSA in eastern Africa it is important to reconstruct the behaviours of humans occupying a range of different places and environments. The purpose of this article is therefore to contribute to the expanding body of data available for Tanzania specifically and eastern Africa more generally. The most significant observation of this study is a long-term change in reduction intensity, raw material selection, and artefact typology at Magubike. It is possible that this trend represents the gradual adjustment of MSA populations to a more mobile lifestyle during MIS 4, which included a generalist approach to lithic technology and a greater focus on raw material optimization. An exploration of the lithic data indicates behaviours consistent with adaptation to gradual environmental deterioration possibly as a result of lower temperatures and rising aridity during MIS 4. Nevertheless, it is important to note that the chronology of Magubike cannot be precisely linked to the climate record of eastern Africa at this time, and this hypothesis is provisional awaiting further data. Planned field research, including paleoenvironmental and geoarchaeological analyses, will help to clarify the context in which MSA humans lived at Magubike, and why their approaches to stone resources changed over time.

Acknowledgements Fieldwork was done thanks to research clearance given to Pamela Willoughby from COSTECH, the Tanzanian Commission on Science and Technology and through an excavation permit from the Division of Antiquities, Ministry of Natural Resources and Tourism, Government of Tanzania. Pamela Willoughby would also like to thank Dr. Pastory Bushozi and the students of the University of Dar es Salaam archaeological field school in 2012 who helped us excavate Magubike. Dr. Anne Skinner of the Department of Chemistry at Williams College produced the ESR dates included in Table 1. She would like to thank the other members of IRAP, the Iringa Region Archaeological Project, for their assistance with this research.

Compliance with Ethical Standards This research was completed with funds from two Standard Research Grants awarded to Pamela Willoughby from SSHRC, the Social Sciences and Humanities Research Council of Canada (grants \#410-2008-0061 and \#410-2011-0117), as well as a Joseph-Armand Bombardier Canada Graduate Scholarships Program: Master's Scholarship (award \# 766-2013-0704) and Joseph-Armand Bombardier Canada Graduate Scholarships Program: Doctoral Scholarship (award \# 767-2015-1885) awarded to J. Jeffrey Werner.

Conflict of Interest The authors declare that they have no conflict of interest.

Open Access This article is distributed under the terms of the Creative Commons Attribution 4.0 International License (http:// creativecommons.org/licenses/by/4.0/), which permits unrestricted use, distribution, and reproduction in any medium, provided you give appropriate credit to the original author(s) and the source, provide a link to the Creative Commons license, and indicate if changes were made.

\section{References}

Ambrose, S. H. (1998). Late Pleistocene human population bottlenecks, volcanic winter, and differentiation of modern humans. Journal of Human Evolution, 34(6), 623-651.

Ambrose, S. H. (2001). Paleolithic technology and human evolution. Science, 291(5509), 1748-1753.

Andrefsky, W. (2005). Lithics: Macroscopic approaches to analysis. New York: Cambridge University Press.

Arzarello, M., Boudad, L., \& Guislain, S. (2013). Middle Paleolithic occupation of the Moroccan Sahara: Open air sites of the Tafilalt. Quaternary International, 300, 131-141.

Bamforth, D. B. (1986). Technological efficiency and tool curation. American Antiquity, 51(1), 38-50.

Barham, L. S. (2002). Backed tools in middle Pleistocene central Africa and their evolutionary significance. Journal of Human Evolution, 43(5), 585-603.

Barut, S. (1994). Middle and Later Stone Age lithic technology and land use in east African savannas. African Archaeological Review, 12(1), 43-72.

Bar-Yosef Mayer, D. E., Vandermeersch, B., \& Bar-Yosef, O. (2009). Shells and ochre in Middle Paleolithic Qafzeh cave, Israel: Indications for modern behavior. Journal of Human Evolution, 56(3), 307-314.

Basell, L. S. (2008). Middle Stone Age (MSA) site distributions in eastern Africa and their relationship to Quaternary environmental change, refugia and the evolution of Homo sapiens. Quaternary Science Reviews, 27(27-28), 2484-2498.

Bicho, N. F. (2002). Lithic raw material economy and huntergatherer mobility in the late glacial and early postglacial in Portuguese prehistory. In L. Fisher \& B. Erikson (Eds.), Lithic raw material economies in late glacial and early 
postglacial Europe (pp. 161-179). BAR International Series 1093. Oxford: Archaeopress.

Biittner, K. (2011). Characterization of Middle and Later Stone Age lithic artifacts from two rockshelter sites in Iringa Region, southern Tanzania. PhD dissertation, University of Alberta.

Blades, B. S. (2003). End scraper reduction and hunter-gatherer mobility. American Antiquity, 68(1), 141-156.

Blome, M. W., Cohen, A. S., Tryon, C. A., Brooks, A. S., \& Russell, J. (2012). The environmental context for the origins of modern human diversity: A synthesis of regional variability in African climate 150,000-30,000 years ago. Journal of Human Evolution, 62(5), 563-592.

Brantingham, P. J., \& Kuhn, S. L. (2001). Constraints on Levallois core technology: A mathematical model. Journal of Archaeological Science, 28(7), 747-761.

Broadhurst, C. L., Wang, Y., Crawford, M. A., Cunnane, S. C., Parkington, J. E., \& Schmidt, W. F. (2002). Brain-specific lipids from marine, lacustrine, or terrestrial food resources: Potential impact on early African Homo sapiens. Comparative Biochemistry and Physiology Part B: Biochemistry and Molecular Biology, 131(4), 653-673.

Burdukiewicz, J. M. (2014). The origin of symbolic behavior of Middle Palaeolithic humans: Recent controversies. Quaternary International, 326-327, 398-405.

Cann, R. L., Stoneking, M., \& Wilson, A. C. (1987). Mitochondrial DNA and human evolution. Nature, 325, 31-36.

Chase, B. M. (2010). South African palaeoenvironments during marine oxygen isotope stage 4: A context for the Howiesons Poort and Still Bay industries. Journal of Archaeological Science, 37(6), 1359-1366.

Clark, J. D. (1988). The Middle Stone Age of East Africa and the beginnings of regional identity. Journal of World Prehistory, 2(3), 235-305.

Clarkson, C. (2010). Regional diversity within the core technology of the Howiesons Poort techno-complex. In S. Lycett \& P. Chauhan (Eds.), New perspectives on old stones (pp. 43-59). New York: Springer.

Clarkson, C. (2013). Measuring core reduction using 3D flake scar density: A test case of changing core reduction at Klasies River Mouth, South Africa. Journal of Archaeological Science, 40(12), 4348-4357.

Clarkson, C., \& Hiscock, P. (2008). Tapping into the past: Exploring the extent of Palaeolithic retouching through experimentation. Lithic Technology, 33(1), 5-16.

d'Errico, F., Henshilwood, C. S., Vanhaeren, M., \& van Niekerk, K. (2005). Nassarius kraussianus shell beads from Blombos cave: Evidence for symbolic behaviour in the Middle Stone Age. Journal of Human Evolution, 48(1), 3-24.

Dibble, H. L., Schurmans, U. A., Iovita, R. P., \& McLaughlin, M. V. (2005). The measurement and interpretation of cortex in lithic assemblages. American Antiquity, 70(3), 545-560.

Douze, K., \& Delagnes, A. (2016). The pattern of emergence of a Middle Stone Age tradition at Gademotta and Kulkuletti (Ethiopia) through convergent tool and point technologies. Journal of Human Evolution, 91, 93-121.

Drake, N. A., Blench, R. M., Armitage, S. J., Bristow, C. S., \& White, K. H. (2011). Ancient watercourses and biogeography of the Sahara explain the peopling of the desert. Proceedings of the National Academy of Sciences, 108(2), 458-462.
Drake, N. A., Breeze, P., \& Parker, A. (2013). Palaeoclimate in the Saharan and Arabian deserts during the Middle Palaeolithic and the potential for hominin dispersals. Quaternary International, 300, 48-61.

Eren, M. I., Greenspan, A., \& Sampson, C. G. (2008). Are Upper Paleolithic blade cores more productive than Middle Paleolithic discoidal cores? A replication experiment. Journal of Human Evolution, 55(6), 952-961.

Faith, J. T., Tryon, C. A., \& Peppe, D. J. (2016). Environmental change, ungulate biogeography, and their implications for early human dispersals in equatorial East Africa. In S. C. Jones \& B. A. Stewart (Eds.), Africa from MIS 6-2: Population dynamics and paleoenvironments (pp. 233245). Dordrecht: Springer.

Finch, J., Leng, M. J., \& Marchant, R. (2009). Late Quaternary vegetation dynamics in a biodiversity hotspot, the Uluguru Mountains of Tanzania. Quaternary Research, 72(1), 111122.

Fu, Q., Mittnik, A., Johnson, P. L. F., Bos, K., Lari, M., Bollongino, R., et al. (2013). A revised timescale for human evolution based on ancient mitochondrial genomes. Current Biology, 23(7), 553-559.

Gould, R. A. (1980). Living archaeology. Cambridge: Cambridge University Press.

Gould, R. A., \& Saggers, S. (1985). Lithic procurement in central Australia: A closer look at Binford's idea of embeddedness in archaeology. American Antiquity, 50(1), 117-136.

Grine, F. E. (2016). The late Quaternary hominins of Africa: The skeletal evidence from MIS 6-2. In S. C. Jones \& B. A. Stewart (Eds.), Africa from MIS 6-2: Population dynamics and paleoenvironments (pp. 323-381). Dordrecht: Springer.

Henrich, J. (2004). Demography and cultural evolution: How adaptive cultural processes can produce maladaptive losses: The Tasmanian case. American Antiquity, 69, 197-214.

Henry, D. O. (1989). Correlations between reduction strategies and settlement patterns. Archeological Papers of the American Anthropological Association, 1(1), 139-155.

Henshilwood, C. S. (2007). Fully symbolic sapiens behaviour: Innovation in the Middle Stone Age at Blombos cave, South Africa. In P. Mellars, K. Boyle, O. Bar-Yosef, \& C. Stringer (Eds.), Rethinking the human revolution: New behavioural and biological perspectives on the origin and dispersal of modern humans (pp. 123-132). Cambridge: Cambridge University Press.

Henshilwood, C. S., \& Marean, C. W. (2003). The origin of modern human behavior. Current Anthropology, 44(5), 627-651.

Henshilwood, C. S., d'Errico, F., Yates, R., Jacobs, Z., Tribolo, C., Duller, G. A. T., Mercier, N., Sealy, J., Valladas, H., Watts, I., \& Wintle, A. (2002). Emergence of modern human behavior: Middle Stone Age engravings from South Africa. Science, 295(5558), 1278-1280.

Henshilwood, C. S., d'Errico, F., Vanhaeren, M., van Niekerk, K., \& Jacobs, Z. (2004). Middle Stone Age shell beads from South Africa. Science, 304(5669), 404-404.

Henshilwood, C. S., d'Errico, F., \& Watts, I. (2009). Engraved ochres from the Middle Stone Age levels at Blombos cave, South Africa. Journal of Human Evolution, 57(1), 27-47.

Hiscock, P., \& Clarkson, C. (2005). Experimental evaluation of Kuhn's geometric index of reduction and the flat-flake problem. Journal of Archaeological Science, 32(7), 1015-1022. 
Hiscock, P., \& Tabrett, A. (2010). Generalization, inference and the quantification of lithic reduction. World Archaeology, 42(4), 545-561.

Hovers, E., Vandermeersch, B., \& Bar-Yosef, O. (1997). A Middle Palaeolithic engraved artefact from Qafzeh cave, Israel. Rock Art Research, 14, 79-87.

Jacobs, Z., Roberts, R. G., Galbraith, R. F., Deacon, H. J., Grün, R., Mackay, A., Mitchell, P., Vogelsang, R., \& Wadley, L. (2008). Ages for the Middle Stone Age of southern Africa: Implications for human behavior and dispersal. Science, 322(5902), 733-735.

Jerardino, A., \& Marean, C. W. (2010). Shellfish gathering, marine paleoecology and modern human behavior: Perspectives from cave PP13B, pinnacle point, South Africa. Journal of Human Evolution, 59(3), 412-424.

Johnson, T. C., Werne, J. P., Brown, E. T., Abbott, A., Berke, M., Steinman, B. A., Halbur, J., Contreras, S., Grosshuesch, S., Deino, A., Lyons, R. P., Scholz, C. A., Schouten, S., \& Sinninghe Damsté, J. S. (2016). A progressively wetter climate in southern East Africa over the past 1.3 million years. Nature, 537(7619), 220-224.

Lahr, M. M., \& Foley, R. A. (2016). Human evolution in late Quaternary eastern Africa. In S. C. Jones \& B. A. Stewart (Eds.), Africa from MIS 6-2: Population dynamics and paleoenvironments (pp. 215-231). Dordrecht: Springer.

Lane, C. S., Chorn, B. T., \& Johnson, T. C. (2013). Ash from the Toba supereruption in Lake Malawi shows no volcanic winter in East Africa at $75 \mathrm{ka}$. Proceedings of the National Academy of Sciences, 110(20), 8025-8029.

Larrasoaña, J. C., Roberts, A. P., \& Rohling, E. J. (2013). Dynamics of green Sahara periods and their role in hominin evolution. PloS One, 8(10), e76514.

Leplongeon, A. (2014). Microliths in the Middle and Later Stone Age of eastern Africa: New data from Porc-Epic and Goda Buticha cave sites, Ethiopia. Quaternary International, 343, 100-116.

Lin, S. C., Douglass, M. J., Holdaway, S. J., \& Floyd, B. (2010). The application of 3D laser scanning technology to the assessment of ordinal and mechanical cortex quantification in lithic analysis. Journal of Archaeological Science, 37(4), 694-702.

Lombard, M. (2005). The Howiesons Poort of South Africa: What we know, what we think we know, what we need to know. Southern African Humanities, 17, 33-55.

Lyons, R. P., Scholz, C. A., Cohen, A. S., King, J. W., Brown, E. T., Ivory, S. J., Johnson, T. C., Deino, A. L., Reinthal, P. N., McGlue, M. M., \& Blome, M. W. (2015). Continuous 1.3million-year record of East African hydroclimate, and implications for patterns of evolution and biodiversity. Proceedings of the National Academy of Sciences, 112(51), 15568-15573.

Mackay, A., \& Welz, A. (2008). Engraved ochre from a Middle Stone Age context at Klein Kliphuis in the western cape of South Africa. Journal of Archaeological Science, 35(6), 1521-1532.

Marean, C. W. (2011). Coastal South Africa and the coevolution of the modern human lineage and the coastal adaptation. In N. F. Bicho, J. A. Haws, \& L. G. Davis (Eds.), Trekking the shore (pp. 421-440). New York: Springer.

Marean, C. W., Bar-Matthews, M., Bernatchez, J., Fisher, E., Goldberg, P., Herries, A. I., Jacobs, Z., Jerardino, A.,
Karkanas, P., et al. (2007). Early human use of marine resources and pigment in South Africa during the Middle Pleistocene. Nature, 449(7164), 905-908.

Marks, A., Shokler, J., \& Zilhão, J. (1991). Raw material usage in the Paleolithic: The effects of availability on selection and economy. In M. Montet-White \& S. Holen (Eds.), Raw material economies among prehistoric hunter-gatherers (pp. 127-140). Lawrence: University of Kansas Publications in Anthropology.

Marwick, B. (2008). What attributes are important for the measurement of assemblage reduction intensity? Results from an experimental stone artefact assemblage with relevance to the Hoabinhian of mainland Southeast Asia. Journal of Archaeological Science, 35(5), 1189-1200.

McBrearty, S. (2013). Advances in the study of the origin of humanness. Journal of Anthropological Research, 69(1), 731.

McBrearty, S., \& Brooks, A. S. (2000). The revolution that wasn't: A new interpretation of the origin of modern human behavior. Journal of Human Evolution, 39(5), 453-563.

McCall, G. S. (2007). Behavioral ecological models of lithic technological change during the later Middle Stone Age of South Africa. Journal of Archaeological Science, 34(10), 1738-1751.

McDougall, I., Brown, F. H., \& Fleagle, J. G. (2005). Stratigraphic placement and age of modern humans from Kibish, Ethiopia. Nature, 433(7027), 733-736.

Mehlman, M. (1989). Late Quaternary archaeological sequences in northern Tanzania. $\mathrm{PhD}$ dissertation, University of Illinois.

Miller, J. M., \& Willoughby, P. R. (2014). Radiometrically dated ostrich eggshell beads from the Middle and Later Stone Age of Magubike Rockshelter, southern Tanzania. Journal of Human Evolution, 74, 118-122.

Mitchell, P. (2008). Developing the archaeology of marine isotope stage 3. Goodwin Series, 10, 52-65.

Mumbi, C. T., Marchant, R., Hooghiemstra, H., \& Wooller, M. J. (2008). Late Quaternary vegetation reconstruction from the Eastern Arc mountains, Tanzania. Quaternary Research, 69(2), 326-341.

Newcomer, M. H. (1971). Some quantitative experiments in handaxe manufacture. World Archaeology, 3(1), 85-94.

Pargeter, J., \& Brandt, S. A. (2015). Lithic technological approaches to the African Late Pleistocene Later Stone Age. Evolutionary Anthropology: Issues, News, and Reviews, 24(5), 167-169.

Parry, W. J., \& Kelly, R. L. (1987). Expedient core technology and sedentism. In J. K. Johnson \& C. A. Morrow (Eds.), The organization of core technology (pp. 285-304). Boulder: Westview Press.

Pickford, M. (1995). Fossil land snails of East Africa and their palaeoecological significance. Journal of African Earth Sciences, 20(3-4), 167-226.

Powell, A., Shennan, S., \& Thomas, M. G. (2009). Late Pleistocene demography and the appearance of modern human behavior. Science, 324(5932), 1298-1301.

Prendergast, M. E., Luque, L., Dominguez-Rodrigo, M., DiezMartin, F., Mabulla, A., \& Barba, R. (2007). New excavations at Mumba rockshelter (Tanzania). Journal of African Archaeology, 5(2), 163-189.

Roberts, P., Henshilwood, C. S., van Niekerk, K. L., Keene, P., Gledhill, A., Reynard, J., Badenhorst, S., \& Lee-Thorp, J. 
(2016). Climate, environment and early human innovation: Stable isotope and faunal proxy evidence from archaeological sites $(98-59 \mathrm{ka})$ in the southern cape, South Africa. PloS One, 11(7), e0157408.

Sandgathe, D. M. (2004). Alternative interpretation of the Levallois reduction technique. Lithic Technology, 29(2), 147-159.

Scholz, C. A., Cohen, A. S., Johnson, T. C., King, J., Talbot, M. R., \& Brown, E. T. (2011). Scientific drilling in the Great Rift Valley: The 2005 Lake Malawi scientific drilling project An overview of the past 145,000 years of climate variability in southern hemisphere East Africa. Palaeogeography, Palaeoclimatology, Palaeoecology, 303(1-4), 3-19.

Schoville, B. J. (2010). Frequency and distribution of edge damage on Middle Stone Age lithic points, pinnacle point 13B, South Africa. Journal of Human Evolution, 59(3-4), 378391.

Shea, J. J. (2011). Homo sapiens is as Homo sapiens was. Current Anthropology, 52(1), 1-35.

Stewart, B. A., \& Jones, S. C. (2016). Africa from MIS 6-2: The florescence of modern humans. In S. C. Jones \& B. A. Stewart (Eds.), Africa from MIS 6-2: Population dynamics and paleoenvironments (pp. 1-20). Dordrecht: Springer.

Stewart, J. R., \& Stringer, C. B. (2012). Human evolution out of Africa: The role of refugia and climate change. Science, 335(6074), 1317-1321.

Stewart, B. A., Dewar, G. I., Morley, M. W., Inglis, R. H., Wheeler, M., Jacobs, Z., \& Roberts, R. G. (2012). Afromontane foragers of the late Pleistocene: Site formation, chronology and occupational pulsing at Melikane Rockshelter, Lesotho. Quaternary International, 270, 40-60.

Toth, N. P. (1987). Behavioral inferences from early stone artifact assemblages: An experimental model. Journal of Human Evolution, 16(7-8), 763-787.

Tryon, C. A., \& Faith, J. T. (2013). Variability in the Middle Stone Age of eastern Africa. Current Anthropology, 54(S8), S234S254.

Tryon, C. A., McBrearty, S., \& Texier, P.-J. (2005). Levallois lithic technology from the Kapthurin Formation, Kenya: Acheulian origin and Middle Stone Age diversity. African Archaeological Review, 22(4), 199-229.
Van Peer, P. (1992). The Levallois reduction strategy (Vol. 13). Madison: Prehistory Press.

Walter, R. C., Buffler, R. T., Bruggemann, J. H., Guillaume, M. M. M., Berhe, S. M., Negassi, B., Libsekal, Y., Cheng, H., Edwards, R. L., von Cosel, R., Néraudeau, D., \& Gagnon, M. (2000). Early human occupation of the Red Sea coast of Eritrea during the last interglacial. Nature, 405(6782), 65-69.

White, T. D., Asfaw, B., DeGusta, D., Gilbert, H., Richards, G. D., Suwa, G., \& Howell, F. C. (2003). Pleistocene Homo sapiens from Middle Awash, Ethiopia. Nature, 423(6941), 742-747.

Wilkins, J., \& Chazan, M. (2012). Blade production 500 thousand years ago at Kathu Pan 1, South Africa: Support for a multiple origins hypothesis for early middle Pleistocene blade technologies. Journal of Archaeological Science, 39(6), 1883-1900.

Wilkins, J., Schoville, B. J., Brown, K. S., \& Chazan, M. (2012). Evidence for early hafted hunting technology. Science, 338(6109), 942-946.

Wilkins, J., Schoville, B. J., Brown, K. S., \& Chazan, M. (2015). Kathu Pan 1 points and the assemblage-scale, probabilistic approach: A response to Rots and Plisson, "Projectiles and the abuse of the use-wear method in a search for impact" Journal of Archaeological Science, 54, 294-299.

Willoughby, P. R. (2007). The evolution of modern humans in Africa: A comprehensive guide. Lanham: Altamira Press.

Willoughby, P. R. (2012). The Middle and Later Stone Age in the Iringa region of southern Tanzania. Quaternary International, 270, 103-118.

Willoughby, P. R., Compton, T., Bello, S. M., Bushozi, P. M., Skinner, A. R., \& Stringer, C.B. (submitted). Middle Stone Age human teeth from the Magubike rockshelter, Iringa Region, Tanzania. PLOS ONE.

Yellen, J. E., Brooks, A. S., Cornelissen, E., Mehlman, M. J., \& Stewart, K. (1995). A Middle Stone Age worked bone industry from Katanda, upper Semliki Valley, Zaire. Science, 268(5210), 553-556.

Ziegler, M., Simon, M. H., Hall, I. R., Barker, S., Stringer, C. B., \& Zahn, R. (2013). Development of Middle Stone Age innovation linked to rapid climate change. Nature Communications, 4, 1905 . 